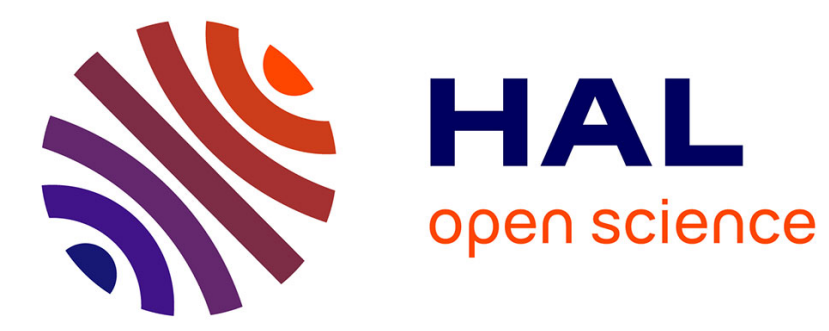

\title{
ISOLATION BY DISTANCE AND VICARIANCE DRIVE GENETIC STRUCTURE OF A CORAL REEF FISH IN THE PACIFIC OCEAN
}

S E Planes, Cécile Fauvelot

\section{- To cite this version:}

S E Planes, Cécile Fauvelot. ISOLATION BY DISTANCE AND VICARIANCE DRIVE GENETIC STRUCTURE OF A CORAL REEF FISH IN THE PACIFIC OCEAN. Evolution - International Journal of Organic Evolution, 2002. ird-03044209

\author{
HAL Id: ird-03044209 \\ https://hal.ird.fr/ird-03044209
}

Submitted on 7 Dec 2020

HAL is a multi-disciplinary open access archive for the deposit and dissemination of scientific research documents, whether they are published or not. The documents may come from teaching and research institutions in France or abroad, or from public or private research centers.
L'archive ouverte pluridisciplinaire HAL, est destinée au dépôt et à la diffusion de documents scientifiques de niveau recherche, publiés ou non, émanant des établissements d'enseignement et de recherche français ou étrangers, des laboratoires publics ou privés. 


\title{
ISOLATION BY DISTANCE AND VICARIANCE DRIVE GENETIC STRUCTURE OF A CORAL REEF FISH IN THE PACIFIC OCEAN
}

\author{
S. Planes ${ }^{1,2,3}$ And C. Fauvelot ${ }^{1,2}$ \\ ${ }^{1}$ Ecole Pratique des Hautes Etudes-ESA CNRS 8046, Université de Perpignan, 66860 Perpignan Cedex, France \\ ${ }^{2}$ Centre de Recherches Insulaires et Observatoire de l'Environnement, BP 1013, Papetoai, Moorea, French Polynesia \\ ${ }^{3}$ E-mail: planes@univ-perp.fr
}

\begin{abstract}
We studied the genetic diversity of a coral reef fish species to investigate the origin of the differentiation. A total of 727 Acanthurus triostegus collected from 15 locations throughout the Pacific were analyzed for 20 polymorphic loci. The genetic structure showed limited internal disequilibrium within each population; $3.7 \%$ of the loci showed significant Hardy-Weinberg disequilibrium, mostly associated with $A d h^{*}$, and we subsequently removed this locus from further analysis of geographic pattern. The genetic structure of A. triostegus throughout the tropical Pacific Ocean revealed a strong geographic pattern. Overall, there was significant population differentiation (multilocus $F_{\text {ST }}$ $=0.199$ ), which was geographically structured according to bootstraps of neighbor-joining analysis on Nei's unbiased genetic distances and AMOVA analysis. The genetic structure revealed five geographic groups in the Pacific Ocean: western Pacific (Guam, Philippines, Palau, and Great Barrier Reef); central Pacific (Solomons, New Caledonia, and Fiji); and three groups made up of the eastern populations, namely Hawaiian Archipelago (north), Marquesas (equatorial), and southern French Polynesia (south) that incorporates Clipperton Island located in the northeastern Pacific. In addition, heterozygosity values were found to be geographically structured with higher values grouped within Polynesian and Clipperton populations, which exhibited lower population size. Finally, the genetic differentiation $\left(F_{\mathrm{ST}}\right)$ was significantly correlated with geographic distance when populations from the Hawaiian and Marquesas archipelagos were separated from all the other locations. These results show that patterns of differentiation vary within the same species according to the spatial scale, with one group probably issued from vicariance, whereas the other followed a pattern of isolation by distance. The geographic pattern for A. triostegus emphasizes the diversity of the evolutionary processes that lead to the present genetic structure with some being more influential in certain areas or according to a particular spatial scale.
\end{abstract}

Key words.-Allozyme, genetic drift, isolation by distance, marine fish, Pacific Ocean, pairwise genetic and geographic distances, population genetics, vicariance.

Received May 14, 2001. Accepted November 5, 2001.

The homogeneity of marine species has been emphasized in previous works and was mainly explained by the relative rarity of strong physical barriers to dispersal (Vermeij 1987). In addition, gene flow has always been viewed as a powerful cohesive force (Slatkin 1987). One effective migrant exchanged between subpopulations per generation is theoretically sufficient to stop them from drifting to fixation of alternative genes, although a higher level of gene flow is required to maintain homogeneity (Allendorf and Phelps 1981). General evidence of genetic homogeneity in marine organisms over large areas (Ward et al. 1994) and theoretical models of speciation seem opposed to the high diversity found in marine ecosystems and raise the question about the conditions that may favor genetic divergence and speciation in groups with planktotrophic larval dispersal (Palumbi 1992). Nevertheless, many marine taxa with high dispersal potential that were once thought to represent a single species spread over large areas are actually sibling species complexes with very low genetic distances, implying recent species formation (Knowlton 1993; Palumbi 1997; Shaklee and Bentzen 1998).

Among the models that can lead to speciation, there are situations in which genetic divergence does occur within continuous distributions. In species with large enough distributions relative to their dispersal capability, isolation by distance can occur (Johnson and Black 1998). The phrase "isolation by distance," was introduced by Wright (1943) to describe the accumulation of local genetic differences under geographically restricted dispersal. The theory of isolation by distance has been developed, jointly with the stepping- stone model of population structure among organisms whose dispersal ability is constrained by distance such that gene flow is most likely to occur between neighboring populations (Kimura 1953; Malécot 1955; Kimura and Weiss 1964). This approach linking gene flow and geographic distance may also provide insights into whether the species has experienced recent expansions or vicariance events (Hellberg 1994).

The theory of isolation by distance has been recently questioned regarding the validity of the patterns observed in relation to the gene flow-drift equilibrium (Slatkin 1993; Hutchinson and Templeton 1999). The initial theoretical model related gene flow, $M\left(=N_{e} m\right)$, estimated according to Wright's (1931) island model, to geographic distance (Slatkin 1993). Even if Slatkin (1993) argues that the gene flow-drift equilibrium is not necessary to establish the model he proposed, it seems inappropriate to compute gene flow using Wright's (1931) island model because it is based on assumption that cannot be verified (Bossart and Prowell 1998; Whitlock and McCauley 1998). The efficiency of such an indirect method to provide estimates of present gene flow is biased by the effect that population history can exert on existing population structure derived from $F_{\mathrm{ST}}$-values (Niegel 1997; Bohonak 1999). As Lewontin (1985) emphasized, model estimates of gene flow will almost never be valid because parameters that define these models are spatially and temporally variable and too sensitive to the forces of evolution. The recent model of Hutchinson and Templeton (1999) aimed to look at the relationship between $F_{\mathrm{ST}}$ and geographic distances, and determined several cases according 
to the equilibrium between drift and gene flow. This model does not make any prior assumption because it only looks at the scatter plot between $F_{\mathrm{ST}}$ and geographic distance and uses the pattern to define the evolutionary state of the population according to spatial scales surveyed. Some recent studies have documented significant correlation between gene flow and geographic distance in most major groups using Slatkin's (1993) model (see review in Pogson et al. 2001). In contrast, many failed to detect correlation in species with limited dispersal capabilities and exhibiting differentiated populations (Kim et al. 1998; Franceschinelli and Kesseli 1999). Overall, it is unclear whether this is due to the model used in estimating gene flow as discussed earlier (Bossart and Prowell 1998), the presence of nonequilibrium conditions, or even the sampling strategies (Williams and Benzie 1998).

Regarding the Indo-West Pacific fauna, there is a great difference in the species diversity between the various regions. The majority of tropical marine families have their greatest concentration of species within a comparatively small triangle formed by the Philippines, the Malay Peninsula, and New Guinea (Briggs 1999). As one leaves this East Indies Triangle to consider the biota of the peripheral areas, there is a notable decrease in species diversity that appears to be correlated with distance and length of the larval stage (Bonhomme and Planes 2000). Reasons for the present-day distribution are complex and are the subject of fascinating studies, many of which are fairly recent and ongoing. Many studies on corals, sea-grasses, mollusks, and fishes (Salvat 1971; Springer 1982; Vermeij 1987; Rosen 1988; Wallace et al. 1989; Kay 1990; Jokiel and Martinelli 1992; Mukai 1992; Pandolfi 1992; Stoddart 1992; Veron 1995) have investigated species distribution and proposed models of colonization and speciation.

In earlier biogeographic works, several authors suggested that the distribution of Pacific taxa could be explained by vicariance (Newman 1986; Kay 1990), and some even suggested that the Pacific tectonic plate is a distinct biogeographic province (Springer 1982; Newman and Foster 1983). The term "vicariance" centralizes the idea that speciation originated from the isolation of some populations resulting from some geographic or climatic break (Rosen 1978). More recently, Randall (1995) suggested vicariant patterns to explain the origin of some of the inshore Hawaiian fish fauna, emphasizing that some of the distribution can only be explained in terms of the geological history of the Pacific plate. Springer's (1982) hypothesis of vicariance has been largely rejected on the basis that an insufficient number of taxa support such a biogeographic pattern and by the pattern of distribution that shows a west-east gradient of the diversity (Briggs 1999) in the Pacific. Earlier genetic data also failed to show evidence of vicariance in the Pacific and suggested long-range dispersal processes with very low genetic distance, reinforcing the hypothesis that populations remain linked through continuing and recent gene flow (Rosenblatt and Waples 1986; Benzie and Williams 1997).

Recent phylogenetic data showed that speciation and radiation of species occurred in recent times (early Pleistocene). The low intraocean levels of mitochondrial DNA variation suggest that the divergence within the Pacific must have been recent in the fish (McMillan and Palumbi 1995; McMillan et al. 1999; Bowen et al. 2001) as well as in sea urchins (Palumbi et al. 1997; Lessios et al. 2001) and mud crab (Gopurenko et al. 1999). For Chaetodontidae, the authors even showed concordant temporal and phylogenetic patterns among independent species groups and suggested that the genetic differentiation was influenced by common environmental factors, therefore favoring vicariant processes (McMillan and Palumbi 1995). For sea urchin species, temporal and phylogenetic patterns varied between groups, suggesting that they may be more likely driven by chance and historical accidents (Palumbi et al. 1997). Overall, examples remain too limited to provide any consensus.

In this paper, we report a survey of allozyme variation in a coral reef fish, Acanthurus triostegus, mostly sampled throughout the Indo-West Pacific (only one location was sampled in the Indian Ocean). The objective of this work was to determine whether A. triostegus, a fish with a long larval life, will exhibit genetically structured population across the $\mathrm{Pa}-$ cific Ocean. In addition, we test the relationship between genetic differentiation and geographic distances to investigate the role of long-distance dispersal and vicariance as evolutionary processes leading to genetic differentiation in the Pacific Ocean.

\section{MATERIALS AND METHODS}

\section{Study Species}

The convict surgeonfish, A. triostegus (Acanthuridae), is found throughout the tropical Indo-Pacific, from South African to Baja Californian reefs. Such a wide distribution contributed to the choice of this species. Sexes are separate and each female can lay more than 100,000 eggs each year (Randall 1961). Reproduction occurs during the day, in groups of hundreds of individuals, near channels through the reef. This species has pelagic eggs and a larval duration estimated at between 60 and 70 days. Pelagic larvae have been reported at about 50-m depth around Hawaii (Randall 1961), while the highest concentrations of larvae were found in 13- to 20$m$ depth in the Great Barrier Reef (Leis 1991). Competent postlarvae returning to the reef measure $20-25 \mathrm{~mm}$ before settlement.

\section{Sampling Design}

A total of 727 surgeonfish ( $>60-\mathrm{mm}$ total length) were captured from 16 localities between 1994 and 1998 (Fig. 1), using spearfishing techniques. Among the 16 locations sampled, we concentrated our effort on the Pacific area and analyzed only one population from the west Indian Ocean (Mozambique), which was used to calibrate the differences between Pacific Ocean locations. Within the Pacific Ocean, our objective was to get representation of most archipelagos that could be used as stepping stones from a dispersal perspective. Due to the sampling difficulties in some areas (e.g., infrequent aerial connection, unavailability of liquid nitrogen), we were unable to include some regions such as the Marshall and Caroline Islands, located in the equatorial Pacific Ocean. Exact details of sampling locations are as follows: samples from Mozambique were collected around Ibo Island; samples from the Philippines came from the Batanga Reefs; specimens 


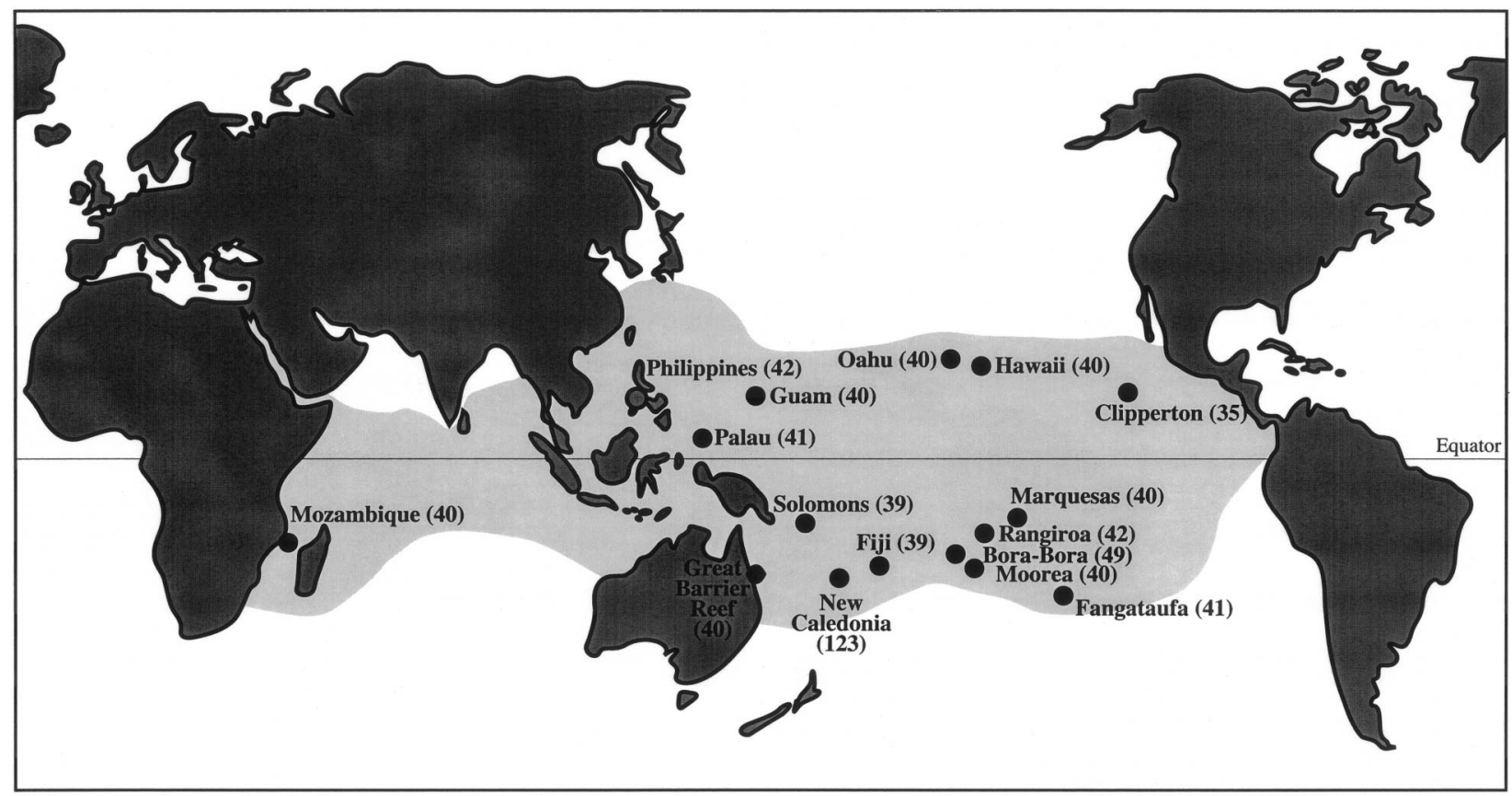

FIG. 1. Location of sampling sites of Acanthurus triostegus within the Indo-Pacific (details of locations are described in the text). Numbers in parentheses are the number of individuals analyzed at each sampling location. The shaded area maps the species' biogeographical range.

from Palau came from the east coast of Koror; individuals from Guam were sampled in front of the Marine Laboratory of Guam University; fish from the Great Barrier Reef were collected at Hyde Reef (central); samples from the Solomon Islands were speared on reefs in front of the International Center for Leaving and Aquatic Resource Management (ICLARM) aquaculture center; specimens from New Caledonia were caught at three sites around New Caledonia; fish from Fiji came from the reef in front of Suva; individuals from the Marquesas were collected in Hua Huka Island; Acanthurus from Oahu were sampled around Coconut Island; fish from Hawaii were collected along the Kona coast; and samples from Bora-Bora, Moorea, Fangataufa, Rangiroa, and Clipperton originated from the lagoon of each island.

A minimum of 40 individuals was collected in each location (excepting the Solomons, Fiji, and Clipperton) to ensure sufficient confidence limits in estimating genetic diversity and allelic frequencies (Allendorf and Phelps 1981). With the exception of collections from Clipperton, sampled by R. Robertson and that from Fangataufa by R. Galzin, all other collections were made by the same scientist (S. Planes), using the same technique, therefore limiting any selective artifacts in the data.

Fish were dissected in the field to isolate the liver and part of the dorsal muscles (a piece of 1-2 g). The tissues were stored in liquid nitrogen in the field and in a $-80^{\circ} \mathrm{C}$ freezer in the laboratory to prevent possible degradation of the enzymatic activity prior to electrophoresis.

\section{Electrophoresis}

Each piece of tissue was homogenized at $4^{\circ} \mathrm{C}$ in an equal volume of Tris/EDTA/NADP buffer $(\mathrm{pH}=6.8)$. Homoge- nates were centrifuged at $15,000 \mathrm{~g}$ for $30 \mathrm{~min}$ at $4^{\circ} \mathrm{C}$ and the supernatants were stored at $-80^{\circ} \mathrm{C}$.

Electrophoresis was performed on starch-gel using three buffers (TBE $\mathrm{pH}=8.0[0.0125 \mathrm{M}$ Tris, $0.0165 \mathrm{M}$ boric acid, $0.00004 \mathrm{M}$ EDTA]; TC $\mathrm{pH}=6.7$ [0.008 M Tris, $0.003 \mathrm{M}$ citric acid], $\mathrm{TC} \mathrm{pH}=8.0$ [0.02 $\mathrm{M}$ Tris, $0.004 \mathrm{M}$ citric acid], and Tris $\mathrm{HCl} \mathrm{pH}=8.5[0.01 \mathrm{M}$ Tris, $\mathrm{HCl}]$ ), according to Pasteur et al. (1987).

The following 20 loci were screened in the populations examined (enzyme nomenclature according to Shaklee et al. 1990): aspartate aminotransferase, E.C. 2.6.1.1 (Aat- $1^{*}$ and Aat-3*; TC 6.7 on muscle, Aat-2*; TC 6.7 on liver); adenosine deaminase, E.C. 3.5.4.4 ( $A d a^{*}$; TC 6.7 on muscle); alcohol dehydrogenase, E.C. 1.1.1.1 ( $A d h^{*}$; Tris $\mathrm{HCl}$ on liver); guanine deaminase, E.C. 3.5.4.3 ( $G d a^{*}$; TC 6.7 on liver); glycerol-3-phosphate dehydrogenase, E.C. 1.1.1.8 (G3pdh*; TC 8.0 on muscle); glucosephosphate isomerase, E.C. 5.3.1.9 (Gpi-1* and Gpi-2*; TC 8.0 on muscle); isocitrate dehydrogenase $\left(\mathrm{Napd}^{+}\right)$, E.C. 1.1.1.42 (Idhp- ${ }^{*}$; TC 6.7 on liver, Idhp-2*; TC 6.7 on muscle); lactate dehydrogenase, E.C. 1.1.1.27 ( $L d h-1 *, L d h-2 *$, and $L d h-3 *$; TC 6.7 on muscle); malate dehydrogenase, E.C. 1.1.1.37 (Mdh*; TC 8.0 on liver); malic enzyme $\left(\mathrm{NADP}^{+}\right)$, E.C. 1.1.1.40 $\left(\mathrm{Mep}-\mathrm{I}^{*}\right.$ and Mep-2*; TC 8.0 on muscle); peptidase leucine-glycine-glycine, E.C. 3.4.11 (Pepb*; TC 6.7 on liver); phosphogluconate dehydrogenase, E.C. 1.1.1.44 ( $P g d h^{*}$; TC 6.7 on liver); and phosphoglucomutase, E.C. 5.4.2.1 (Pgm*; TBE 8.0 on muscle).

\section{Genetic Analysis}

Allelic and genotypic frequencies for the polymorphic locus were obtained by counting phenotypes directly from the 


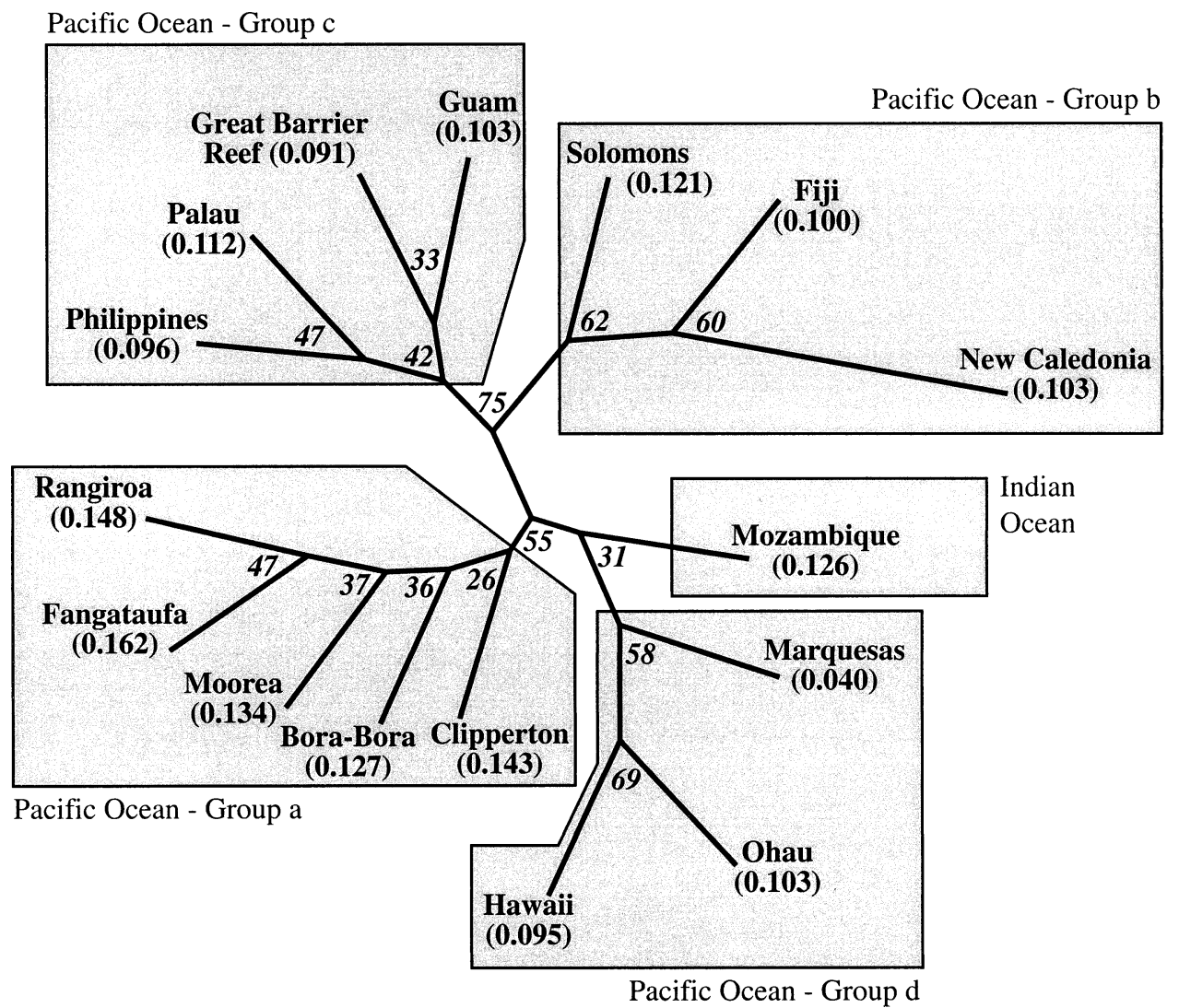

FIG. 2. Neighbor-Joining phenogram depicting genetic distance relationships of Acanthurus triostegus based on nonbiased Nei's distances $(D ;$ Nei 1978) among all samples. Adh* was removed from this analysis (see comment in text). Number in italics on the nodes represent the percentage of bootstrap replicates (1000 iterations). Branch lengths are proportional to the genetic distances between populations. Observed heterozygosity values of each population are shown in parentheses following the name of each population. Group designations follow the description detailed in the text.

gels and computed using the GENETIX package (Bonhomme et al. 1993, available via www.univ-montp2.fr/ genetix/ genetix.htm). Observed heterozygosity values were computed for each population from the genotypic frequencies and by adding monomorphic loci for multilocus values (Nei 1973). Heterozygosity values were assessed with their estimates of variance and standard deviations generated by resampling over loci (available on the GENETIX package). Genetic differences among the populations were assessed through their variation in genetic diversity (number of alleles and heterozygosity).

Nonbiased genetic distances ( $D$; Nei 1978) were computed for all pairwise comparisons (for each locus separately and over all loci) and the resulting matrix was used to produce a neighbor-joining dendrogram (using PHYLIP 3.5, software available via http://evolution.genetics.washington.edu/ phylip.html). Topological confidence was evaluated with 1000 bootstrap replicates for neighbor-joining using the SEQBOOT and CONSENS subroutines in the PHYLIP 3.5 package (Felsenstein 1985). In addition to the bootstrapping method, we conducted a hierarchical analysis of molecular variance (AMOVA; Excoffier et al. 1992, Arlequin 2.00 software available via http://anthro.unige.ch/arlequin) to test the significance of the partition of the total genetic variance. Total genetic variation was partitioned according to the subdivi- sions described previously by the neighbor-joining analysis, so that we compared three levels: among groups (or subdivisions), among populations within groups, and among individuals within populations.

$F$-statistics were calculated from Weir and Cockerham (1984) to estimate the parameters $F, f$, and $\theta$ (unbiased estimates of $F_{\mathrm{IT}}, F_{\mathrm{IS}}$, and $F_{\mathrm{ST}}$, respectively; Wright 1951). Probabilities of random departure from zero for single locus $\theta$ values were calculated using exact test (Raymond and Rousset 1995a), which allows corrections for rare alleles and small sample size. $F$-statistics were computed using the GENETIX 2.0 package. Significance of $F_{\mathrm{ST}^{-}}$values and probabilities for divergence from Hardy-Weinberg equilibrium were estimated using GENEPOP software (Raymond and Rousset 1995b). Probabilities were corrected according to the sequential Bonferroni procedure (Rice 1989).

Correlation between geographic distances and genetic differentiation was tested for each locus and over all loci using Mantel's test based directly on the distribution of 10,000 randomized matrices computed by permutation (Mantel 1967). Mantel's test was performed using the MANTEL procedure of the GENETIX package. In such correlations, we followed Hutchison and Templeton's model (1999), which directly links $F_{\mathrm{ST}}$ and geographical distances. This recent approach removed the problems of relating the estimate of 
TABLE 1. Distribution of Acanthurus triostegus alleles in each population. Only alleles that were not present in all populations are presented $\left(A D H^{*}\right.$ data were omitted because they were not used in further analysis). "Frequent alleles" are alleles that are found in more than $5 \%$ of the collections but are not present in all populations. "Rare alleles" are present less than 5\% and occur sporadically among the populations. Alleles at each locus were identified by their electrophoretic mobility relative to that of the most common allele in the overall population (cf. Appendix 2). 1, allele present in population; blank, allele absent.

\begin{tabular}{|c|c|c|c|c|c|c|c|c|c|c|c|c|c|c|c|c|c|c|c|c|c|c|c|}
\hline & \multicolumn{14}{|c|}{ Frequent alleles } & \multicolumn{9}{|c|}{ Rare alleles } \\
\hline Philippines & 1 & 1 & & 1 & 1 & 1 & 1 & & & & & & & 6 & & 1 & & 1 & 1 & & & 1 & \\
\hline Palau & 1 & 1 & 1 & 1 & 1 & 1 & 1 & & 1 & & & & & 8 & 1 & & 1 & & & & & & \\
\hline Guam & 1 & 1 & 1 & 1 & 1 & 1 & 1 & 1 & 1 & & & & & 9 & 1 & 1 & 1 & & & 1 & & & \\
\hline Great Barrier Reef & 1 & 1 & & 1 & 1 & & 1 & 1 & 1 & 1 & 1 & 1 & & 10 & & 1 & & 1 & & & & 1 & \\
\hline Fiji & 1 & 1 & 1 & 1 & 1 & 1 & 1 & 1 & & 1 & & & & 9 & 1 & & & 1 & & & & & 1 \\
\hline Bora-Bora & 1 & 1 & 1 & 1 & 1 & 1 & 1 & 1 & 1 & 1 & & & 1 & 11 & & 1 & & & & & & & 1 \\
\hline Moorea & 1 & 1 & 1 & 1 & 1 & 1 & & & 1 & 1 & 1 & & & 9 & 1 & 1 & & 1 & & & & & \\
\hline Fangataufa & 1 & 1 & 1 & 1 & 1 & 1 & & 1 & 1 & 1 & 1 & & & 10 & 1 & 1 & 1 & & & & 1 & & \\
\hline Rangiroa & 1 & 1 & 1 & 1 & 1 & 1 & 1 & 1 & 1 & & 1 & & & 10 & 1 & 1 & 1 & & 1 & & & 1 & \\
\hline Marquesas & & & 1 & & & & & & & 1 & & 1 & & 3 & 1 & & 1 & 1 & & 1 & & & \\
\hline Oahu & 1 & 1 & 1 & & & 1 & 1 & 1 & & & & 1 & 1 & 8 & 1 & 1 & & & 1 & 1 & 1 & & \\
\hline
\end{tabular}

regional $F_{\mathrm{ST}}$ to gene flow and the subsequent question linked to the genetic equilibrium assumed by the island model.

\section{RESULTS}

A total of 20 loci could be unambiguously interpreted. Of these, one locus $(L d h-3 *)$ was monomorphic, and seven loci (G3pdh*, Gpi-2*,Idhp-1*,Idhp-2*,Ldh-1*,Ldh-2*,Mep-2*) displayed a low level of polymorphism, with the most commonly appearing allele showing frequencies higher than $95 \%$.

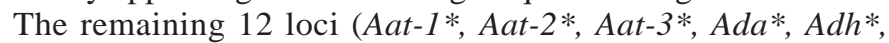
Gda*, Gpi-1*, Mdh*, Mep-1*,Peph*,Pgdh*,Pgm*) were polymorphic and exhibited moderate to high levels of heterozygosity (Appendix 1). The mean overall $P_{0.95}$ and $P_{0.99}$ values ( 0.50 and 0.75 , respectively) suggest that $A$. triostegus is among the most polymorphic species of marine fish studied to date (Planes 1997). Polymorphism values varied enormously among samples with $P_{0.95}$ ranging from 0.20 (the Marquesas) to 0.55 (Clipperton) and $P_{0.99}$ from 0.40 (the Marquesas) to 0.75 (Guam and Solomons). Mean observed heterozygosity for the species was equal to 0.117 , but such values varied among populations, with the lowest value for the Marquesas sample (0.045) and the highest for the Fangataufa population $(0.181)$.

Departure from Hardy-Weinberg equilibrium was investigated using $F_{\text {IS }}$-values. Eight loci showed significant departures from Hardy-Weinberg equilibrium over 217 tests ( $3.7 \%$; we omitted the analyses on the overall population). For the eight significant values, six exhibited excess of homozygotes due to the presence of a single homozygote for a rare allele. Single-locus disequilibria were mostly observed in $A d h *$ (five of eight significant). Significant single-locus Hardy-Weinberg disequilibrium for $A d h *$ led to multilocus disequilibrium in some populations (Philippines, Solomons, Fiji, and Oahu). Overall, the number of significant tests is less that the number expected due to sampling error $(5 \%$ of $217=10.25)$ and was shown to be related to the presence of homozygotes for rare alleles. Because a single locus ( $\left.A d h^{*}\right)$ displayed most of the disequilibrium, we could not ignore the hypothesis that these deviations originated from misscoring of the zymograms. Thus, in later analyses we omitted $A d h *$ to remove any potential scoring artifact. After removing $A d h^{*}$, only Oahu still showed significant multilocus HardyWeinberg disequilibrium, which was due to the presence of a single homozygote for a rare allele in $A d a^{*}$.

The first comparisons of locations throughout the IndoPacific were based on the distribution of alleles (Table 1). Frequent alleles are certainly the most interesting because there is little chance to miss them when they exist in a population given the sample sizes used in this study. The distribution of the 13 frequent alleles identified for A. triostegus did not show any clear-cut differences between populations. However, we distinguished genetically diversified locations such as ones exhibiting 10 or more frequent alleles (Mozambique, Great Barrier Reef, Solomons, New Caledonia, Bora-Bora, Rangiroa, and Fangataufa) from less diversified ones with nine or fewer frequent alleles (Philippines, Palau, Guam, Fiji, Moorea, Hawaii, Oahu, the Marquesas, and Clipperton). In addition to the 13 frequent alleles, 32 rare alleles were also observed. The distribution of rare alleles followed almost the same pattern as frequent alleles, with some exceptions such as the high number of rare alleles in Hawaii (10) compared to the Solomons (six) or New Caledonia (seven). Overall, rare alleles were randomly spread with five to eight alleles in each population, except in Bora-Bora and the Great Barrier Reef, which had three and four, respectively, and Hawaii, which had 10. Among the 32 rare alleles, 12 were found only once in one population and eight were found twice in two populations. Due to the very low frequencies of some alleles, analysis of rare alleles gives little phylogenetic information. Overall, there was no strong geographic pattern in the distribution of rare alleles.

The following analysis concentrated on variation of allelic 
TABle 1. Extended.

\begin{tabular}{|c|c|c|c|c|c|c|c|c|c|c|c|c|c|c|c|c|c|c|c|c|c|c|c|c|}
\hline \multicolumn{25}{|c|}{ Rare alleles } \\
\hline $\begin{array}{c}\text { Mep-2 } \\
* 90\end{array}$ & & & & 1 & & & & & & & & & & & & 1 & & & & & & & 6 & 12 \\
\hline \multirow[t]{3}{*}{1} & & & & 1 & & 1 & & & & & & & & & 1 & & & & & & & & 6 & 14 \\
\hline & & & & & & & 1 & & 1 & 1 & & & & & & & 1 & & & & & & 8 & 17 \\
\hline & & & 1 & & & & & & & & & & & & & & & & & & & & 4 & 14 \\
\hline \multirow{2}{*}{1} & & 1 & & & & & & & & & & & & & & & & & & & & 1 & 5 & 14 \\
\hline & & & & & & & 1 & & & & & & & & & & & & & & & & 3 & 14 \\
\hline \multirow[t]{5}{*}{1} & & 1 & & & & & & & & & & & & & & & & & 1 & & & & 6 & 15 \\
\hline & & & & & & & & & & & & & & & & & & 1 & & 1 & & & 6 & 16 \\
\hline & & & & & & & & & & & & & & & & & & & & & & & 5 & 15 \\
\hline & & & & & 1 & & & 1 & & & & & & & & & & & & & & & 6 & 9 \\
\hline & 1 & 1 & & & & & & & & & & & & & & & & & & & & & 7 & 15 \\
\hline
\end{tabular}

frequencies among locations. Marked differences in the frequencies of alleles at several loci were observed among populations (Appendix 2). Major variations appeared in six loci (Aat-2*, Aat-3*,Ada*, Gda*, Gpi-2*, and Mdh*). Aat-2*100 varied from a fixed status in Mozambique, Philippines, Fiji, Marquesas, and Hawaii to 0.43 in Bora-Bora, with low frequencies in Polynesia (Bora-Bora, Fangataufa, and Rangiroa) and Clipperton. Aat $3 * 100$ also varied from a fixed status in the Marquesas and Hawaii to 0.55 in the Philippines, with higher frequencies in the eastern Pacific and the Indian Ocean and lower ones in the western Pacific. Distinction between eastern and western Pacific samples was also observed for $A d a^{*}$, for which the allele 100 dominated in the western locations, whereas it decreased in the eastern sites. $G d a * 100$ varied from 0.94 in Guam to 0.48 in Oahu. The main variation in Gpi-2* came from the Mozambique population, where the dominant allele (100) had a frequency below 50\%. Mdh* showed three groups, with one consisting of western Pacific and Indian Ocean samples, one of Polynesian sites, and a one consisting of Hawaiian Islands and the Marquesas; the frequency of $M d h * 100$ decreased in this order, whereas $M d h * 50$ increased. Despite some major variations, none of the loci showed different alleles fixed in different populations, suggesting that gene flow maintains the cohesion of the species throughout its range.

Nei's genetic distances were used to generate an unrooted tree through a neighbor-joining analysis (Fig. 2). The dendrogram clustered geographically proximate locations together. Four major groups within the Pacific Ocean came out of the analysis: (1) Polynesia and Clipperton Island; (2) central Pacific (Fiji, New Caledonia, and Solomons); (3) western Pacific (Philippines, Great Barrier Reef, Palau, and Guam); and (4) Hawaiian Islands and Marquesas. In addition to these four groups, the Indian Ocean sample (Mozambique) diverged significantly, and we considered it as separate group. This analysis was done integrating all loci simultaneously (except $A d h^{*}$ ). Similar analyses were computed for each locus (the 11 most polymorphic ones mentioned earlier and Gpi$2 *$ that showed large variation of allelic frequencies among populations) separately to determine the impact of each one. All loci (except Aat-1*) contributed to separate some populations, suggesting that the multilocus pattern resulted from the interaction of several loci. However, some loci showed similar patterns, such as $G d a^{*}, P g d h^{*}$, and $P e p b^{*}$ that contributed to isolate the two Hawaiian populations, or $A d h *$ and Aat $-2 *$ that separated Polynesian populations. In contrast, some differentiation was mostly derived from a single locus, such as $G p i-2 *$ isolating the Marquesas population or $M d h *$ segregating Fangataufa from other Polynesians islands.

We reported the observed heterozygosity values on the multilocus neighbor-joining tree computed from Nei's genetic distances (Fig. 2). Heterozygosity values within the Pacific Ocean can be split into three major groups: (1) the maximum heterozygosity values $(0.127$ to 0.162 , mean $=$ 0.143 ) are found in eastern samples (Fangataufa, Clipperton, Rangiroa, Bora-Bora, and Moorea); (2) the central Pacific, western Pacific, and Hawaiian areas showed heterozygosity values varying from 0.091 in the Great Barrier Reef to 0.121 in the Solomons with a mean value of 0.103; and (3) the Marquesas sample showed a much lower heterozygosity value (0.040). Overall, mean heterozygosity of the Polynesian group (0.143) showed an increase of $40 \%$ compared to other groups. Single-factor ANOVA performed using the four groups of the Pacific Ocean extracted from the neighborjoining analysis demonstrated significant difference in $H_{\mathrm{o}}$ among the groups $(F=8.722$, df $=3, P=0.003)$. Scheffe's post hoc tests confirmed that the difference was due to Polynesian groups in which samples showed significant higher $H_{\mathrm{o}}$ than other groups $(P=0.005$ and 0.037 with Hawaii and western Pacific, respectively).

Over all locations, the multilocus $F_{\mathrm{ST}^{-v a l u e}}(0.199)$ was highly significant $(P<0.0001)$, and 14 loci showed signif- 
TABle 2. Matrix of pairwise $F_{\mathrm{ST}^{-}}$values between Pacific Acanthurus triostegus populations. Above the diagonal are the multilocus $F_{\mathrm{ST}}$-values with the straight-line geographic distance (nautical miles) between each pair of samples denoted below in parentheses. Only polymorphic loci were included in the analysis and $A d h *$ data were omitted because they were not used in the multilocus analysis. Almost all pairwise comparisons show significant divergence of genotypic frequencies (according to exact test computed with GENEPOP 2.0) with a few exceptions identified by an asterisk following the $F_{\mathrm{ST}}$-values $(* P>0.05)$. Below the diagonal are the individual loci showing significant $F_{\mathrm{ST}}$-values. Loci are encoded as follows: a, Aat-1*; b, Aat-2*; c, Aat-3*; d, Ada*; e, Gda*; f, G3pdh*; g, Gpi-1*; h, Gpi-2*; i, Idhp-1*; j, Idhp-2*; k, Ldh-1*; 1, Ldh-2*; m, $L d h-3 * ; \mathrm{n}, M d h^{*} ; \mathrm{o}, M e p-1 * ; \mathrm{p}, M e p-2^{*} ; \mathrm{q}, P e p b^{*} ; \mathrm{r}, P g d h^{*} ; \mathrm{s}, P g m^{*}$.

\begin{tabular}{|c|c|c|c|c|c|c|}
\hline & Philippines & Palau & Guam & $\begin{array}{c}\text { Great } \\
\text { Barrier Reef }\end{array}$ & Solomons & $\begin{array}{c}\text { New } \\
\text { Caledonia }\end{array}$ \\
\hline Philippines & - & $\begin{array}{l}0.0086^{*} \\
(845)\end{array}$ & $\begin{array}{l}0.0298 \\
(1341)\end{array}$ & $\begin{array}{l}0.0217 \\
(2593)\end{array}$ & $\begin{array}{l}0.0555 \\
(2659)\end{array}$ & $\begin{array}{l}0.0651 \\
(3394)\end{array}$ \\
\hline Palau & o & - & $\begin{array}{r}0.0282 \\
(718)\end{array}$ & $\begin{array}{l}0.0225 \\
(1830)\end{array}$ & $\begin{array}{l}0.0177 \\
(1815)\end{array}$ & $\begin{array}{l}0.0310 \\
(2554)\end{array}$ \\
\hline Guam & $\mathrm{b}, \mathrm{c}, \mathrm{d}, \mathrm{o}$ & $\mathrm{c}, \mathrm{e}$ & - & $\begin{array}{l}0.0167 \\
(2014)\end{array}$ & $\begin{array}{l}0.0672 \\
(1644)\end{array}$ & $\begin{array}{l}0.0495 \\
(2467)\end{array}$ \\
\hline Great Barrier Reef & $\mathrm{e}, \mathrm{o}, \mathrm{s}$ & $\mathrm{e}, \mathrm{g}, \mathrm{s}$ & $\mathrm{b}, \mathrm{d}, \mathrm{e}$ & - & $\begin{array}{l}0.0678 \\
(1858)\end{array}$ & $\begin{array}{r}0.0589 \\
(974)\end{array}$ \\
\hline Solomons & $\mathrm{b}, \mathrm{c}, \mathrm{o}$ & $\mathrm{e}, \mathrm{h}$ & $\mathrm{c}, \mathrm{e}, \mathrm{h}$ & $\mathrm{e}, \mathrm{r}$ & - & $\begin{array}{r}0.0121 \\
(849)\end{array}$ \\
\hline New Caledonia & $\mathrm{a}, \mathrm{c}, \mathrm{e}, \mathrm{o}, \mathrm{s}$ & $\mathrm{c}, \mathrm{e}, \mathrm{s}$ & $\mathrm{b}, \mathrm{d}, \mathrm{e}, \mathrm{q}$ & $\mathrm{e}, \mathrm{s}$ & $\mathrm{c}, \mathrm{e}$ & - \\
\hline Fiji & $\mathrm{e}, \mathrm{o}$ & $\mathrm{e}$ & $\mathrm{b}, \mathrm{d}, \mathrm{e}$ & $\mathrm{e}, \mathrm{s}$ & $\mathrm{b}, \mathrm{e}$ & $\mathrm{f}, \mathrm{h}, \mathrm{s}$ \\
\hline Bora-Bora & $\mathrm{b}, \mathrm{c}, \mathrm{e}, \mathrm{n}, \mathrm{o}, \mathrm{s}$ & $\mathrm{b}, \mathrm{c}, \mathrm{n}, \mathrm{r}, \mathrm{s}$ & $\mathrm{b}, \mathrm{c}, \mathrm{d}, \mathrm{e}, \mathrm{n}$ & $\mathrm{b}, \mathrm{c}, \mathrm{e}, \mathrm{n}, \mathrm{r}$ & $\mathrm{b}, \mathrm{c}, \mathrm{n}$ & $\mathrm{b}, \mathrm{c}, \mathrm{f}, \mathrm{n}$ \\
\hline Moorea & $\mathrm{b}, \mathrm{c}, \mathrm{d}, \mathrm{n}, \mathrm{o}$ & $\mathrm{c}, \mathrm{d}, \mathrm{e}, \mathrm{n}$ & $\mathrm{d}, \mathrm{n}, \mathrm{s}$ & $\begin{array}{l}\mathrm{b}, \mathrm{c}, \mathrm{d}, \\
\mathrm{e}, \mathrm{n}, \mathrm{r}, \mathrm{s}\end{array}$ & $\mathrm{c}, \mathrm{d}, \mathrm{e}, \mathrm{n}$ & $\mathrm{b}, \mathrm{d}, \mathrm{e}, \mathrm{n}, \mathrm{s}$ \\
\hline Fangataufa & $\mathrm{b}, \mathrm{c}, \mathrm{d}, \mathrm{e}, \mathrm{n}, \mathrm{o}$ & $\mathrm{b}, \mathrm{c}, \mathrm{d}, \mathrm{n}$ & $\mathrm{b}, \mathrm{c}, \mathrm{d}, \mathrm{e}, \mathrm{n}$ & $\begin{array}{c}\mathrm{b}, \mathrm{c}, \mathrm{d}, \mathrm{e}, \mathrm{g}, \\
\mathrm{n}, \mathrm{s}\end{array}$ & $\mathrm{b}, \mathrm{c}, \mathrm{d}, \mathrm{n}$ & $\mathrm{b}, \mathrm{c}, \mathrm{d}, \mathrm{n}$ \\
\hline Rangiroa & $\mathrm{b}, \mathrm{c}, \mathrm{d}, \mathrm{n}, \mathrm{o}$ & $\mathrm{b}, \mathrm{c}, \mathrm{d}, \mathrm{n}$ & $\mathrm{b}, \mathrm{d}, \mathrm{n}$ & $\begin{array}{l}\mathrm{b}, \mathrm{c}, \mathrm{d}, \mathrm{e}, \mathrm{n}, \\
\mathrm{r}, \mathrm{s}\end{array}$ & $\mathrm{b}, \mathrm{c}, \mathrm{d}, \mathrm{e}, \mathrm{n}, \mathrm{h}$ & $\mathrm{b}, \mathrm{d}, \mathrm{e}, \mathrm{n}$ \\
\hline Marquesas & $\begin{array}{c}\mathrm{c}, \mathrm{e}, \mathrm{g}, \mathrm{h}, \mathrm{n}, \\
\mathrm{o}, \mathrm{r}, \mathrm{s}\end{array}$ & $\mathrm{c}, \mathrm{g}, \mathrm{h}, \mathrm{n}, \mathrm{r}, \mathrm{s}$ & $\begin{array}{c}\mathrm{r}, \mathrm{b}, \mathrm{c}, \mathrm{d}, \mathrm{e} \\
\mathrm{g}, \mathrm{h}, \mathrm{n}\end{array}$ & $\begin{array}{c}\mathrm{c}, \mathrm{e}, \mathrm{g}, \mathrm{h}, \mathrm{n}, \\
\mathrm{r}, \mathrm{s}\end{array}$ & $\begin{array}{c}\mathrm{b}, \mathrm{c}, \mathrm{e}, \mathrm{g}, \mathrm{n} \\
\mathrm{o}, \mathrm{r}, \mathrm{s}\end{array}$ & $\begin{array}{c}\mathrm{c}, \mathrm{e}, \mathrm{g}, \mathrm{h}, \mathrm{n}, \\
\mathrm{r}, \mathrm{s}\end{array}$ \\
\hline Oahu & $\begin{array}{c}\mathrm{c}, \mathrm{d}, \mathrm{e}, \mathrm{g}, \mathrm{n}, \\
\mathrm{o}, \mathrm{q}, \mathrm{r}, \mathrm{s}\end{array}$ & $\begin{array}{c}\mathrm{c}, \mathrm{d}, \mathrm{e}, \mathrm{g}, \mathrm{n}, \\
\mathrm{q}, \mathrm{r}, \mathrm{s}\end{array}$ & $\mathrm{b}, \mathrm{d}, \mathrm{e}, \mathrm{g}, \mathrm{n}, \mathrm{q}$ & $\begin{array}{c}\mathrm{b}, \mathrm{c}, \mathrm{d}, \mathrm{e}, \mathrm{g}, \\
\mathrm{n}, \mathrm{q}, \mathrm{r}\end{array}$ & $\mathrm{b}, \mathrm{c}, \mathrm{d}, \mathrm{g}, \mathrm{h}, \mathrm{n}, \mathrm{q}, \mathrm{r}$ & $\begin{array}{r}\text { a,c,d,e,g, } \\
\text { h,n,q,r,s }\end{array}$ \\
\hline Hawaii & $\begin{array}{c}\mathrm{c}, \mathrm{e}, \mathrm{g}, \mathrm{n}, \mathrm{o}, \\
\mathrm{q}, \mathrm{r}, \mathrm{s}\end{array}$ & $\begin{array}{c}\mathrm{c}, \mathrm{e}, \mathrm{g}, \mathrm{n}, \mathrm{q}, \\
\mathrm{r}, \mathrm{s}\end{array}$ & $\begin{array}{c}\mathrm{c}, \mathrm{d}, \mathrm{e}, \mathrm{g}, \mathrm{n}, \\
\mathrm{q}, \mathrm{r}\end{array}$ & $\mathrm{c}, \mathrm{e}, \mathrm{n}, \mathrm{q}, \mathrm{r}$ & $\begin{array}{c}\mathrm{b}, \mathrm{c}, \mathrm{g}, \mathrm{h}, \mathrm{n}, \\
\mathrm{o}, \mathrm{q}, \mathrm{r}\end{array}$ & $\begin{array}{c}\mathrm{a}, \mathrm{c}, \mathrm{e}, \mathrm{g}, \mathrm{n}, \\
\mathrm{q}, \mathrm{r}, \mathrm{s}\end{array}$ \\
\hline Clipperton & $\mathrm{b}, \mathrm{c}, \mathrm{e}, \mathrm{p}$ & $\mathrm{b}, \mathrm{c}, \mathrm{d}, \mathrm{p}, \mathrm{g}$ & $\mathrm{b}, \mathrm{c}, \mathrm{d}, \mathrm{e}, \mathrm{p}$ & $\begin{array}{c}\mathrm{b}, \mathrm{c}, \mathrm{d}, \mathrm{e}, \mathrm{n}, \\
\mathrm{p}, \mathrm{s}\end{array}$ & $\mathrm{b}, \mathrm{c}, \mathrm{d}, \mathrm{p}$ & $\begin{array}{c}\mathrm{a}, \mathrm{b}, \mathrm{c}, \mathrm{d}, \mathrm{g}, \\
\mathrm{n}, \mathrm{p}, \mathrm{s}\end{array}$ \\
\hline
\end{tabular}

icant divergence (only $I d h p-1 *, I d h p-2 *, L d h-1 *$, and $L d h-2 *$ were not significant and $L d h-3 *$ was monomorphic). Significant $F_{\mathrm{ST}^{-}}$-values ranged from $0.0101\left(\mathrm{Pgm}^{*}\right)$ to $0.203(\mathrm{Mdh} *)$. Once removing the Indian Ocean sample (Mozambique), $F_{\mathrm{ST}}$ became higher $(0.273)$ with the same loci remaining significantly divergent from zero. When looking at pairwise comparisons (Table 2), most pairs (100 of 105) showed significant genetic divergence with $F_{\mathrm{ST}}$ that varied from zero $(-0.0019)$ between the Solomons and Fiji to 0.4271 between the Great Barrier Reef and the Marquesas. Significant divergence was also found between closer populations such as Moorea and Bora-Bora (0.1127) or Oahu and Hawaii (0.0941; Table 2). Regarding the divergence between Indian and Pacific Oceans, multilocus $F_{\mathrm{ST}^{-}}$-values between Mozambique, Guam, Philippines, Palau, and the Great Barrier Reef varied between 0.2107 and 0.2491 , demonstrating pronounced genetic divergence similar to the level of divergence observed within the Pacific Ocean between Hawaii or the Marquesas and other locations. When looking at each locus individually and correcting $P$-values according to Bonferroni procedure, 544 pairwise comparisons were significant with $70 \%$ occurring at five loci (Aat-2*,Aat-3*,Ada*, Gda*, and Mdh*; Table 2).

The genetic and geographic structures were examined using an analysis of hierarchical molecular variance (AMOVA). We performed the AMOVA using the four groups of the
Pacific Ocean (Polynesia, central Pacific, western Pacific, and Hawaiian and Marquesas archipelagoes) extracted from the neighbor-joining analysis. The division among the four groups accounted for a substantial amount of the molecular variance (15.5\%; Table 3). Examination of the hierarchical $\Phi$-statistics indicated that most of the variance is found within populations (78.3\%; Table 3). Jointly, the amount of variance found among populations within groups is still remarkable $(6.3 \%)$, suggesting some heterogeneity between populations within the same group. When looking at single-locus AMOVA (Table 4), six loci had a substantial amount of the variance explained by the division into groups (Aat-2*, Aat-3*, $A d a^{*}, G d a^{*}, L d h-l^{*}$, and Mep- $2^{*}$ ), and four loci had a relatively high percentage of variance at the within-group level $\left(\right.$ Aat $-2 *, A d a^{*}, M d h^{*}$, and Mep-2*).

Global analysis of geographic distances and $F_{\mathrm{ST}}$ demonstrated a general significant relationship $(r=0.355, P=$ $0.0002)$ but that only explains $12.6 \%$ of the total variance. A scatter plot of the $F_{\mathrm{ST}^{-}}$-values and the geographic distances (nautical miles) between all Pacific population pairs showed a structured scatter, both when Hawaii, Oahu, and the Marquesas only were paired with the other Pacific locations and when these three locations were excluded from the pairwise comparisons (Fig. 3). Therefore, we computed separate relationships for each group distinguished in the scatter plot. 
TABLE 2. Extended.

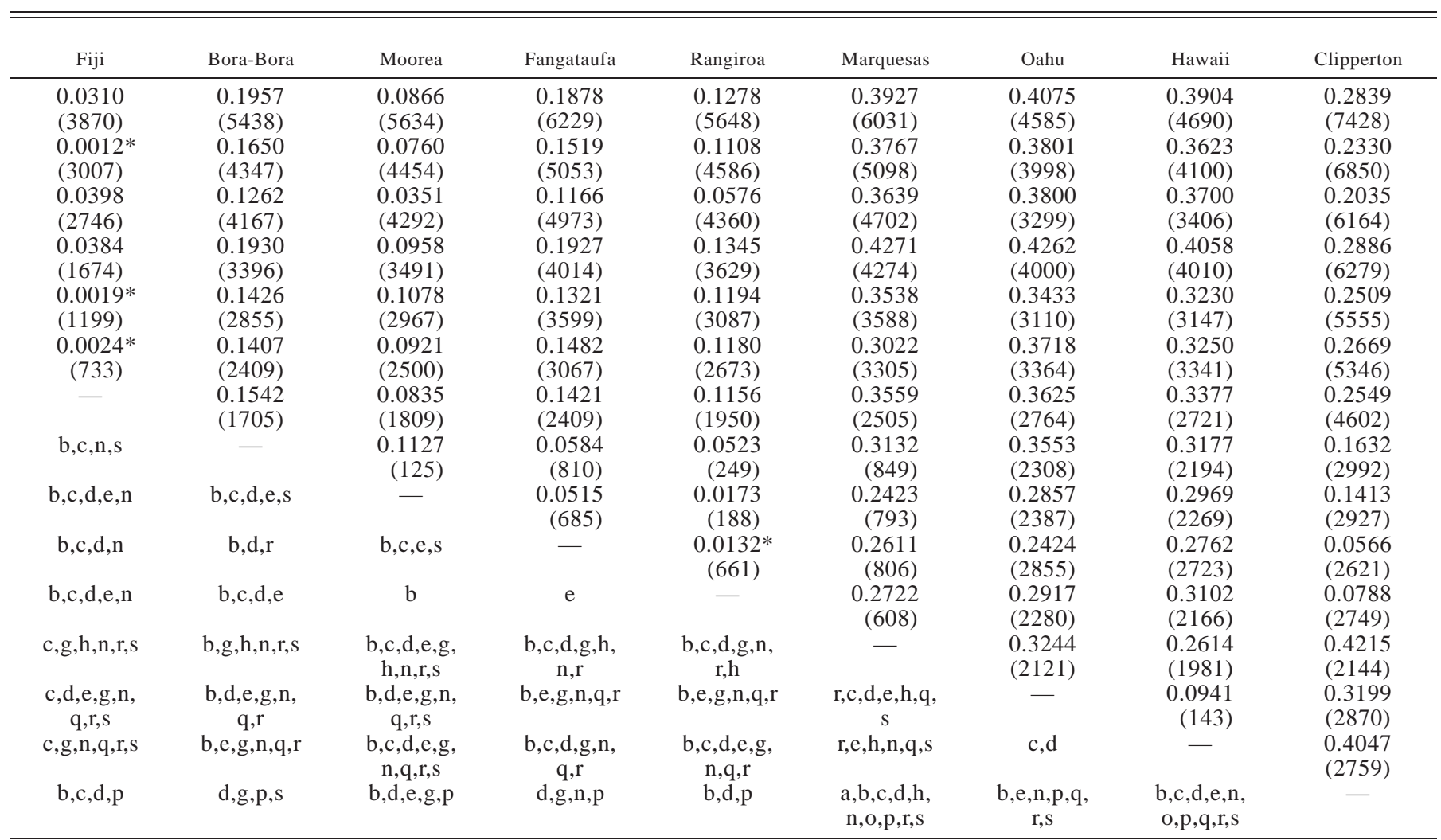

Pairwise comparisons of the Hawaii, Oahu, and Marquesas samples provided a significant positive correlation: $y=0.229$ $+3.6 \times 10^{-5} x, r=0.718, P<0.0001$. Pairwise comparisons between all locations except Hawaii, Oahu, and the Marquesas also provided a significant positive correlation: $y=0.008$ $+3.1 \times 10^{-5} x, r=0.730, P<0.0001$. Both relationships were highly significant, indicating an increase of $F_{\mathrm{ST}}$-values as geographic distances increase. These two relationships differed by their intercept (0.229 vs. 0.008), which suggested that populations of Hawaii, Oahu, and the Marquesas show a marked differentiation compared to all the other locations within the Pacific. However, the differentiation between these three locations (Hawaii, Oahu, and the Marquesas) and all other Pacific populations remains correlated with geographic distance.

Similar analyses were performed for each single locus. The marked step of differentiation between the populations of Hawaii, Oahu, and the Marquesas and other Pacific locations was found for $M d h^{*}, P e p b^{*}, P g h d^{*}$, even though significant correlation with geographic distance was only observed in $M d h^{*}$ among these three loci. When looking at the correlation computed over all locations, three loci (Aat-2*, Aat-3*, and $\left.A d a^{*}\right)$ showed a significant relationship (Table 5). Based on the previous correlation found when separating the Hawaiian and Marquesas archipelagos from all other Pacific populations, the analysis performed for each locus considered a

TABLE 3. Results of hierarchical analysis of molecular variance (AMOVA) for three levels of geographic structure derived from the neighborjoining dendrogram computed from allelic frequencies. Only polymorphic loci were included in the analysis and $A d h^{*}$ data were omitted because they were not used in the multilocus analysis. $P$-values, calculated from a random permutation test (10,000 replicates), and $\Phi$-statistics represent the probability of obtaining by chance alone a more extreme variance than the observed values (Excoffier et al. 1992).

\begin{tabular}{|c|c|c|c|c|c|}
\hline Source of variation & df & $\begin{array}{c}\text { Variance } \\
\text { components }\end{array}$ & $\begin{array}{l}\text { Percentage } \\
\text { of variance }\end{array}$ & $\Phi$-statistics & $P$ \\
\hline Among groups & 3 & 0.2243 & 15.47 & $\Phi_{\mathrm{SC}}=0.2175$ & $<0.0001$ \\
\hline Among populations within groups & 11 & 0.0911 & 6.28 & $\Phi_{\mathrm{ST}}=0.0743$ & $<0.0001$ \\
\hline Within populations & 1359 & 1.1347 & 78.25 & $\Phi_{\mathrm{CT}}=0.1547$ & $<0.0001$ \\
\hline
\end{tabular}




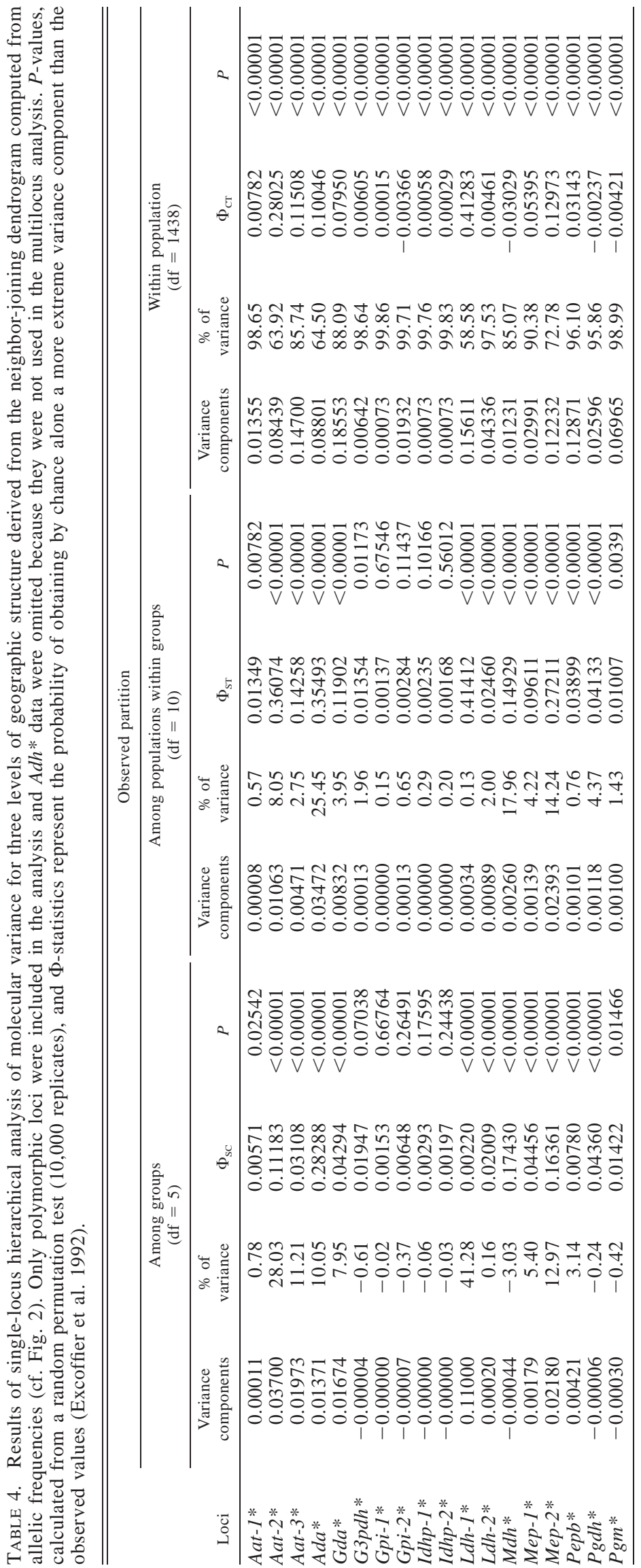




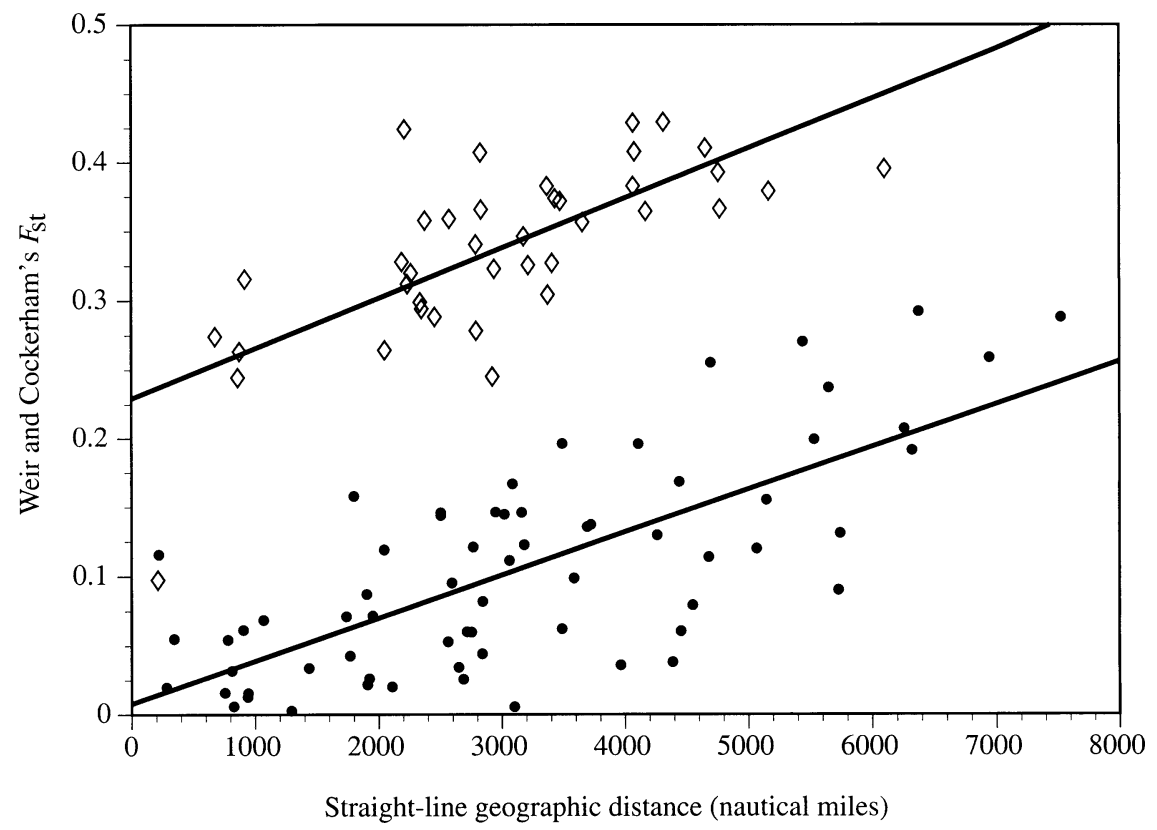

FIG. 3. Relationship between multilocus $F_{\mathrm{ST}}$-values (omitting $A d h *$ ) and straight-line geographic distances (nautical miles) for pairwise comparisons using the 15 Acanthurus triostegus populations from the Pacific Ocean (the population from Mozambique was excluded from this analysis). We separated pairwise comparisons between Hawaii, Oahu, and the Marquesas samples and the other locations (open diamonds) from pairwise comparisons of all locations except Hawaii, Oahu, and the Marquesas (dark circles).

similar separation and demonstrated variable single-locus patterns. The relationship between $F_{\mathrm{ST}}$ and geographic distances for Aat-3* was similar when looking at all populations or isolating the Hawaiian and Marquesas archipelagos. Aat$2 *$ and $M d h^{*}$ showed significant relationships in both cases but with very different intercept values, with $F_{\mathrm{ST}}$-values of $A A T-2 *$ being negatively correlated with geographic distance. $A d a^{*}, G p i-I^{*}, M e p-I^{*}$, and $P e p b^{*}$ were significantly correlated only in one case, suggesting that the addition of other pairwise comparisons adds noise to the relationship. Finally, $G d a *, G p i-2 *, P g d h *$ and $P g m *$ did not show any significant correlation. The multilocus pattern seems to be randomly distributed over loci, following the hypotheses that genetic drift is responsible for the evolution of the divergence among populations.

\section{DisCUSSION}

\section{Genetic Structure of Acanthurus triostegus throughout the} Pacific Ocean

The allozyme survey of $A$. triostegus populations over the Pacific and Indian (Mozambique) Oceans showed strong divergence between populations, with multilocus $F_{\mathrm{ST}}$-values up to 0.42 . In this study, the polymorphism level found in most enzymes (12 highly polymorphic loci and seven with low polymorphism levels) provided 47 independent alleles

TABlE 5. Pearson's correlation $(r)$ between $F_{\mathrm{ST}_{\mathrm{T}}}$-values and geographic distances for pairwise comparisons of Pacific populations computed for each locus and multilocus (all 18 polymorphic loci were included in the analysis and $A d h^{*}$ data were omitted). Significance of correlation computed according to the Mantel algorithm is denoted by an asterisk $(P<0.05)$. Values in parentheses are the intercept of the linear regression for significant correlation.

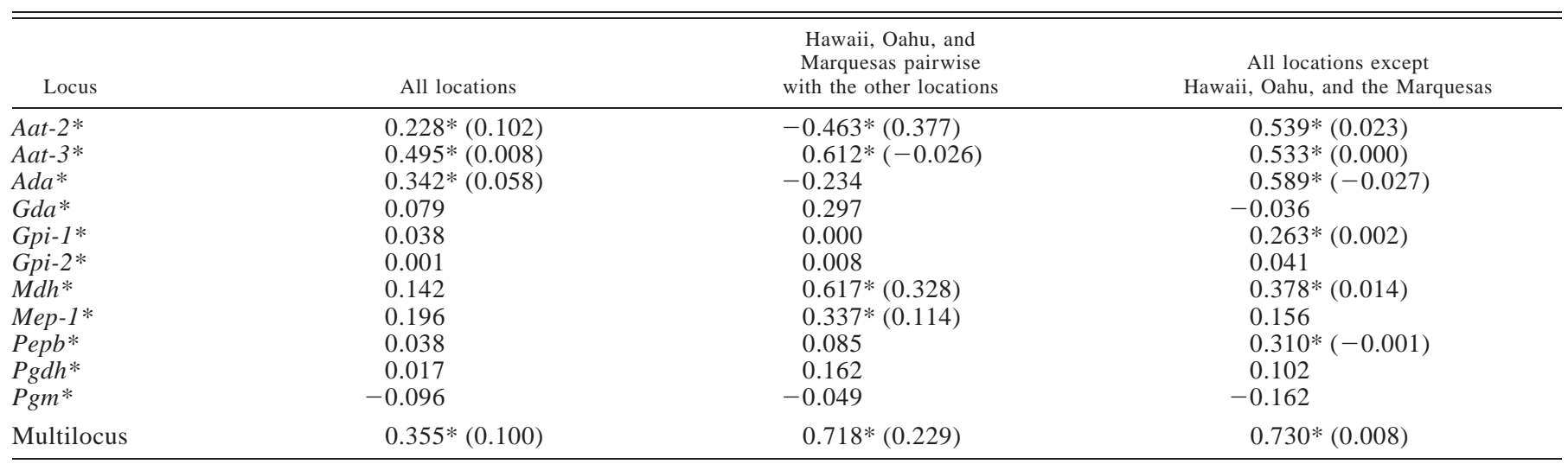


that certainly contribute to increasing the analytical power of allozyme markers compared to most other studies that surveyed fewer polymorphic locus. As mentioned earlier, gene flow is a powerful cohesive force (Allendorf and Phelps 1981; Slatkin 1987). Consequently any significant divergence indicates at least a partial barrier to gene flow, provided that genes are not subject to local selection. Usual precautions involve comparing the distribution of gene expression with frequencies expected under models of simple Mendelian inheritance and screening variation across a wide range of putative gene loci. In the present survey, significant departures from Hardy-Weinberg equilibrium were found in less than $5 \%$ of the 217 single-locus tests performed, suggesting that internal disequilibrium within populations had little effect on genetic variation among populations. Such a significant population structure is even more surprising considering the dispersal capabilities of surgeonfish larvae. Acanthurus triostegus larvae remain in the plankton between 44 to 60 days (mean $=53$ days, $n=90$ individuals; McCormick 1999), and the swimming capabilities of their settlement stage enable forced swims of up to 60 nautical miles under laboratory conditions (Stobutzki and Bellwood 1997). These data seem contrary to the high divergence $\left(F_{\mathrm{ST}}=0.1127\right)$ found between populations of Moorea and Bora-Bora, which are only 125 nautical miles apart. This last result corroborates previous direct measures of dispersal, which emphasized selfrecruitment in coral reef fish populations (Jones et al. 1999; Swearer et al. 1999). Initial genetic work on A. triostegus within French Polynesia already proposed a metapopulation, defined as a patchy population model, in which all patches are occupied and reproductively active, although with few successful migrations between neighboring populations (Planes et al. 1996). This model describes a subdivided population that is stable through time, with gene flow small enough to allow significant local differentiation in neutral gene frequency, but high enough to prevent differential fixation in the long term, and therefore preserving the genetic cohesion of the species. This model was only valid for a restricted spatial scale within an archipelago. The fundamental basis of this model was the existence of differentiated populations only separated by a few nautical miles (Planes 1993), indicating that self-recruitment was the main process in maintaining populations. Biological and behavioral mechanisms allowing larvae to maintain themselves remain unclear, but we suggest that the self-recruitment process derives from some homing behavior as proposed for Anguilla anguilla larvae (Wirth and Bernatchez 2001).

Even if marked genetic differentiation were already observed in A. triostegus between island populations within French Polynesia (Planes 1993; Planes et al. 1996), this is not a standard observation for marine species surveyed over large areas of the Pacific Ocean. Shaklee and Bentzen (1998) proposed four major models of genetic pattern from a large review on marine fish and shellfish. These patterns ranged from species highly subdivided over small distances to species that can show little or no subdivision over large distance, considering also species showing local isolation or major break due to oceanographic or historical effects. Overall, most surveys up to now described little or no subdivision over large distances. Within the Pacific Ocean, earlier work on milkfish (Chanos chanos) failed to find any genetic difference between populations from the Philippines and the Line Islands, and only Hawaiian populations showed differentiated genetic structure (Winans 1980). But it is not clear whether adults, as well as larvae, can also contribute to migration of milkfish. More recent studies on the coconut crab, Birgus latro (Lavery et al. 1996), giant clams, Tridacna spp. (Benzie and Williams 1995, 1997), sea urchin, Echinometra spp. (Palumbi et al. 1997), Linckia starfish (Williams and Benzie 1998), crown-of-thorns starfish, Acanthaster plancii (Benzie 1999), and mud crab, Scylla serrata (Gopurenko et al. 1999) provided evidence of much higher gene flow across the Pacific $\left(F_{\mathrm{ST}}\right.$ or equivalent indices varied from 0.00 to $0.05)$ than the present $A$. triostegus results within the Pacific Ocean $\left(F_{\mathrm{ST}} \approx 0.27\right)$, although patterns of gene flow varied from one species to another.

Surveys on coconut crab, crown-of-thorns starfish, Linckia starfish, and mud crab mentioned above emphasized a major break between Indian Ocean and Pacific Ocean populations. In the case of $A$. triostegus, the Mozambique population shows significant divergence from Pacific Ocean populations and some distinct breaks in Aat-3*, Gda*, and Gpi-2* (cf. Appendix 2). More surprising is the similarity in some allele frequencies between the Mozambique and the Hawaiian collections even though they differ substantially from those of most other Pacific samples. Because we have only a single sample originating from the Indian Ocean, it is difficult to conclude on this special feature as well as on the existence of a break along the Indonesia axis. Analysis of collections from the eastern Indian Ocean should resolve this uncertainty.

The A. triostegus survey describes a new pattern of genetic structure throughout the tropical Pacific compared to some invertebrate species, with the evidence of four geographic groups within the Pacific (without considering the Indian Ocean, Mozambique). This pattern was validated by both AMOVA and bootstrap analysis. The giant clams (Tridacna deresa, T. gigas, and T. maxima) showed a similar pattern, with a high level of gene flow between the Philippines and the Great Barrier Reef, whereas Fijian and Micronesian populations were more isolated (Benzie and Williams 1997). In some way, this is similar to what we found for Acanthurus, for which the Philippines and Great Barrier Reef populations group together. However, Fiji and the Solomons appear in the same group for A. triostegus, whereas they are highly divergent for Tridacna. The Acanthurus genetic pattern appears geographically structured, with a group made up of the western populations (Guam, Philippines, Palau, and Great Barrier Reef), a central Pacific group made of the Micronesian populations (Solomons, New Caledonia, and Fiji), and two groups made up of the eastern populations (north and equatorial, Marquesas and Hawaii, and south, French Polynesia). Separation between western and Micronesian samples is supported by relatively high bootstrap values considering the intraspecific analysis (75\%). One sample seems to be a clear exception: Clipperton appears related to French Polynesian populations (also shows similar heterozygosity value; discussed later) while being located in the northeastern Pacific, and therefore in the same oceanographic currents as Hawaiian collections. The reasons for such similarity remain unclear and are probably related to the origin and/or the history of 
the species because there are no specific geomorphologic or oceanographic characteristics that could link Clipperton to French Polynesia.

Among all surveys looking at large-scale genetic structure, only the surveys on sea urchins (Echinometra mathaei and E. oblonga) included both Hawaiian and Polynesian samples (Palumbi et al. 1997). These two species demonstrated different patterns, with $E$. mathaei exhibiting limited gene flow $\left(N_{e} m<1\right)$ between Hawaii, Polynesia, and western populations, whereas E. oblonga shows substantial gene flow between Hawaii and Polynesia and limited exchanges between the two eastern locations and western ones. The A. triostegus pattern is consistent with the E. mathaei structure and shows significant divergence between Polynesian populations and both Hawaiian and Marquesan ones. The high genetic divergence of Hawaiian populations confirms the taxonomic descriptions that conferred a subspecies name (sandwicensis) to Hawaiian A. triostegus (Randall 1961). In addition to separating Hawaiian and Polynesian populations, the survey of A. triostegus also segregated out the Marquesas population. This result is concordant with a previous genetic survey (Planes 1993), as well as with the survey results of up to $20 \%$ for the endemism of the marine fauna of the Marquesas. This biogeographic isolation of the Marquesas owes its origin to the prevailing currents of this area (Rougerie and Wauthy 1986). The Marquesas countercurrent (South Equatorial Counter Current) flows east to west, opposite to the South Equatorial Current, and the border between these two currents constitutes a barrier for larvae (Vermeij 1987). Finally, the strong genetic divergence among Hawaiian, Marquesan, and Polynesian populations originated because they lie along a north-south axis that is perpendicular to the prevailing current pattern flowing along an east-west axis, creating a barrier to gene flow.

The most significant results on the genetic structure of $A$. triostegus populations are: (1) the high divergence found between populations, even between geographically close ones such as Moorea and Bora-Bora (separated by approximately 140 nautical miles), suggesting limited exchange between nearby islands and favoring the recent idea that self-recruitment mostly maintains populations; and (2) the evidence of five genetic units within the Pacific that correspond to the geographic distribution of the populations. Overall, this study demonstrates that the distance between archipelagos is large enough to build up significant population structure even for high dispersal marine species.

\section{Genetic Diversity Distribution}

Heterozygosity values were found to be geographically structured, with higher values grouped within Polynesian and Clipperton populations, whereas other locations exhibited lower values. The distribution of heterozygosity values matches the genetic structure described from allelic frequencies grouping Polynesian and Clipperton populations (Fig. 2 ). The distribution of heterozygosity differs from all previous surveys. Most surveys found similar values all over the Pacific Ocean (Williams and Benzie 1997; Winans 1980), whereas others observed peripheral populations located in the eastern Pacific showing low mitochondrial DNA diversity compared to the heterozygosity of western populations, such as for sea urchins (Palumbi et al. 1997) or the Ridley sea turtle (Bowen et al. 1998).

Theoretically, in isolated populations the equilibrium-state heterozygosity (also called steady-state level of heterozygosity) is a direct function of the effective population size $\left(N_{e}\right)$ and the mutation rate $\left(\mu=10^{-6}\right.$ for allozymes; Voelker et al. 1980) according to the model $H=4 N_{e} \mu /\left(4 N_{e} \mu+1\right)$. Because the mutation rate is fairly stable for allozymes over the species analyzed so far (between $10^{-6}$ and $10^{-7}$; Voelker et al. 1980), we can assume that heterozygosity of A. triostegus will be mainly driven by the effective population size. Estimates of effective population size are often approximate for present-day populations and it is therefore almost impossible to evaluate change in effective population size through geological time. This is even more approximate in island populations, which have certainly experienced a founder effect initially and probably some bottleneck through geological time. To compare heterozygosity values with potential effective population size of the different locations, we used estimates of areas of coral reefs for each location, assuming that larger coral reef areas maintain larger populations (Planes et al. 1996). Regarding areas covered by coral reefs, larger areas are found along the Australian coast (Great Barrier Reef) and in the Indonesian, Melanesian, and Philippines triangle, which represent about $40 \%$ of total coral reefs, compared to the Polynesian islands, which account for only 4\% (Smith 1978). We can therefore hypothesize that small isolated areas, such as remote islands in the Pacific Ocean, will maintain small population size (e.g., because of small habitat availability) and will also show higher probability of reduction in population size through time. Consequently, remote isolated islands should exhibit lower heterozygosity values. However, higher heterozygosity values were found in some remote locations that exhibit reduced coral reef areas such as Clipperton (0.143) or the Polynesian islands $(0.127$ to 0.162$)$, whereas lower values were found in larger reef areas such as the Great Barrier Reef (0.091) and the Philippines (0.096). All islands did not exhibit high heterozygosity (e.g., Hawaii, Fiji, New Caledonia, and the Marquesas).

We propose two main hypotheses that could lead to the discrepancy between potential population size based on coral reef area and heterozygosity values. First, the present-day population size of A. triostegus is not related to the surface area of coral reefs. Acanthurus triostegus is a widespread species found in abundance across the Indo-Pacific, and even if its density varies according to the geological and ecological specificity of some areas, the differences are not up to a level that the species becomes rare (Randall 1961). Because we are looking at large differences in coral reef areas, we can be confident of some nonparametric relationship between surface areas of reef and population size of A. triostegus. Second, under genetic drift alone (i.e., due to finite population size), the heterozygosity declines through time ( $t$, number of generations) as the inbreeding coefficient rises because the effective size $\left(N_{e}\right)$ is reduced, according to the following model $H_{t}=\left(1-0.5 N_{e}\right)^{t} H_{0}($ Strickberger 1968). This model suggests that the stability of the population will have implications on the level of heterozygosity with an older and stable popu- 


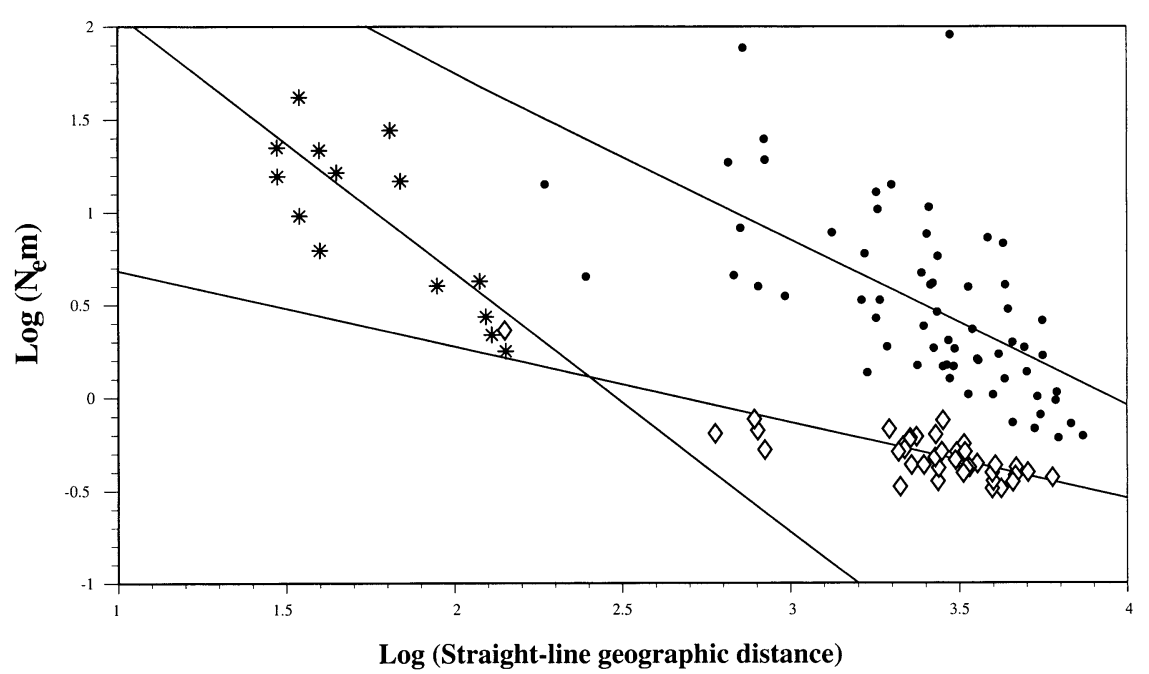

FIG. 4. Relationship between log-transformed multilocus $F_{\mathrm{ST}}$-values $\left(\log \left[1-F_{\mathrm{ST}}\right] / 4 F_{\mathrm{ST}}\right)$, according to the Slatkin's (1993) model, and $\log$ of the straight-line geographic distances (nautical miles) for pairwise comparisons of Pacific Acanthurus triostegus populations. We plotted two different datasets (cf. Fig. 3). Pairwise comparisons including Hawaii, Oahu, and the Marquesas samples (open diamonds) provided a significant negative correlation: $y=1.093-0.409 x, r^{2}=0.684, P<0.001$. Pairwise comparisons for all locations except Hawaii, Oahu, and the Marquesas (dark circles) also provided a significant negative correlation: $y=3.535-0.894 x, r^{2}=0.383, P<$ 0.001. Pairwise comparisons using within-archipelago data (Society Archipelago-French Polynesia) from Planes et al. (1996) (asterisk) provided a significant negative correlation: $y=3.465-1.396 x, r^{2}=0.655, P<0.001$. Significance was computed using Mantel's test because points were not independent.

lation reaching its steady-state equilibrium, whereas younger and/or unstable populations show lower heterozygosity values. This theoretical approach applied to our data would suggest that Polynesian populations are old and have been stable for a long time, such that they express high levels of heterozygosity close to their equilibrium state, whereas other populations showing lower values have recently undergone change in their structure. Change in sea level has contributed to modifying coral reef extension and thus ecosystems according to transgression and regression. Regarding the actual ecology of A. triostegus, change in habitat structure will have a minor effect on population density because it is among the most ubiquitous species that is found in fringing reefs, barrier reefs, and outer slopes (Galzin 1987). Overall, it is almost impossible to conclude whether the variation of heterozygosity indicates recent reduction in population size leading to genetic drift or depicts some pattern of older colonization (Lewontin 1985).

\section{Isolation by Distance in the Tropical Pacific}

The genetic differentiation $\left(F_{\mathrm{ST}}\right)$ among Pacific populations was significantly correlated with geographic distance. However, the pattern appeared more complex than the traditional single relationship with the existence of two structured groups (Fig. 3). Linear relationships computed between genetic differentiation and geographic distance for both groups of populations explained more than $50 \%$ of the total variance $\left(r^{2}=0.516\right.$ and 0.533 , respectively). Apart from larval dispersal, the different relationships between genetic differentiation and geographic separation in A. triostegus could conceivably result from selection acting on allozymes, as was shown in the Atlantic cod when comparing correlation computed with allozymes and DNA markers (Pogson et al. 1995). The multilocus pattern described from our dataset was found to be concordant with the results for several individual loci (four and six loci, respectively, for the two graphs), suggesting that natural selection on allozyme markers seems unlikely to drive relationships. The correlation between gene flow and geographic distances remained significant when processing several analyses removing a different locus from the multilocus $F_{\mathrm{ST}}$ computations, refuting the hypothesis that natural selection on one locus could have created a geographic gradient of differentiation. This approach also reinforces the assumption that selection has little impact on the genetic structure observed for A. triostegus throughout the tropical Pacific.

The relationship we found cannot be directly compared to most previous work that used Slatkin's (1993) model and related logarithmic transformed gene flow and geographic distances. Analyzing our data according to Slatkin's model, a similar pattern for the two datasets was observed (Fig. 4). There was a significant correlation between estimated gene flow and geographical distance with the pairwise comparison between the Hawaiian and Marquesas archipelagos and the other locations, exhibiting a higher correlation value $\left(r^{2}=\right.$ $0.684)$ than the comparison of all the other locations $\left(r^{2}=\right.$ $0.383)$. Such a level of variance explained by the relationship between estimated gene flow and geographic distance is unexpected when compared to previous results in the tropical Pacific Ocean, which show no relationship (Williams and Benzie 1998; Benzie 1999) or a weak one (Palumbi et al. 1997).

Relationships between estimated gene flow and distance have already been documented in marine fish with high dispersal capabilities (Pogson et al. 1995, 2001; Wirth and Bernatchez 2001). In Atlantic cod (Gadus morhua), these researchers observed a similar relationship when dealing within the northwestern Atlantic Ocean (with geographic distances 
less than 900 nautical miles) or across the species' entire geographic range (up to 4000 nautical miles between populations). For A. triostegus, previous results have already demonstrated a significant correlation $\left(r^{2}=0.655\right)$ between estimated gene flow and geographical distances within the scale of the Society Archipelago (French Polynesia) with islands distant by 145 nautical miles maximum (Planes et al. 1996). When considering all samples from all archipelagos of French Polynesia (distant of up to 1015 nautical miles), correlation between estimated gene flow and distance accounted for almost $40 \%$ of the total variance but was not significant. It was suggested that exchange of individuals is favored between neighboring populations, whereas long-distance migrations are more sporadic. The present data contradict this last hypothesis, and we have demonstrated that even long-distance migrations are correlated to geographic distance up to the scale of the entire tropical Pacific Ocean. The main difference among the relationships is the slope of the linear regression (Fig. 4). Slope values vary from -1.40 for the relationship within the Society Archipelago (computed from Planes et al. 1996) to -0.89 among the populations spread over the Pacific Ocean (without Hawaiian and Marquesas Archipelagos; present data) and -0.41 for the relationship incorporating the Hawaiian and Marquesan populations. In the present study, we observed an exponential increase of estimated gene flow as the spatial scale decreased.

The question that remains open is related to the origin of the two relationships found in the present dataset, rather than a single one, because we are dealing with a similar spatial scale. The marked difference in the relationship between genetic differentiation and geographic distances, between Hawaiian and Marquesan populations together, and all other Pacific populations clearly indicates that gene flow among populations is not only a function of the physical distance that separates populations of $A$. triostegus. The most significant example arises when looking at the Marquesas population: The Marquesas Islands are geographically close to the Tuamotu and Society Archipelagos but appeared genetically distant and were found genetically closer to the Hawaiian Archipelago. Regarding the relationship between gene flow and geographic distances (Fig. 4), the group made up of the Hawaiian and Marquesan populations showed also a strong divergence in the intercept, which was much lower (1.09) than within the Society Archipelago (3.46) or over the larger scale of the Pacific (3.53). Currents have often been proposed to explain genetic differentiation in marine species, but analyses using present-day currents have failed to find better relationships (Palumbi et al. 1997). In earlier work, the isolation of the Marquesas population was already explained by the current pattern of the area (Planes 1993). However, it seems that when considering the populations of the Hawaiian and Marquesas Archipelagos, we are dealing with isolated populations that show similar gene flow within an archipelago (cf. the $F_{\mathrm{ST}}$ between Oahu and Hawaii, Table 2) but almost no exchange with all other populations in the tropical Pacific Ocean. These observations favor the hypothesis of biogeographic vicariance as an evolutionary process leading to the differentiation of the A. triostegus populations in the Hawaiian and Marquesas Archipelagos. Vicariant process is usually support by a congruent biogeographic pattern shared by several taxa and/or several independent genetic markers within a species (Avise et al. 1987). Congruence in the biogeographic distribution of some Hawaiian and Marquesan coral reef fish has been emphasized, although not always convincingly (Springer 1982; Newman and Foster 1983; Randall 1995). Regarding allozyme loci in A. triostegus, some show unique patterns for both the Marquesas and Hawaiian archipelagos (Aat-3* and $\left.M d h^{*}\right)$, whereas others are specific to Hawaii $\left(G d a^{*}, P g d h^{*}, P e p b^{*}\right)$ or to the Marquesas (Gpi$2 *)$. Both genetic and biogeographic patterns favor the hypothesis of vicariant processes leading to the actual genetic structure. Other results have demonstrated that the genetic patterns do not fit with the actual current pattern because they integrated several past changes in climate and water mass circulation (Benzie and Williams 1995, 1997). Assuming that Hawaiian and Marquesan reefs were colonized during special climatic and oceanographic conditions, a later climatic break could have since isolated these populations.

The scenario proposed for A. triostegus indicates the diversity of the evolutionary processes that led to the present genetic structure. Limits to any further interpretation result mostly from the diversity of evolutionary forces and their variability through time according to climatic and geological transitions. Such complexity is highlighted by the variability of the genetic pattern already observed in the tropical Pacific Ocean (Benzie and Williams 1997; Palumbi et al. 1997; Williams and Benzie 1997; Gopurenko et al. 1999; McMillan et al. 1999).

\section{ACKNOWLEDGMENTS}

Special thanks goes to anonymous reviewers for their helpful comments. We gratefully acknowledge the assistance in sampling specimens. Special thanks go to P. Colin and L. Colin from Palau; C. Feidler, M. Morlmon, and J. Randall from Hawaii; M. Palomares, who organized the sampling in the Philippines; R. Galzin for collecting specimens from Fangataufa; G. Planes for his help in catching specimens from Rangiroa; R. Robertson for collecting specimens from Clipperton; C. Chauvet and Y. Letourneur for the facilities they offered in New Caledonia; J. Bell was helpful in the Solomons; the University of South Pacific in Fiji; P. Doherty, who helped and taught us how to catch coral reef fish in the Great Barrier Reef; the Ardoukoba Association who sponsored the sampling in Mozambique; and Y. Chancerelle who helped in the Marquesas Islands. This study was supported by grants from PNDB (French National Program on Biodiversity).

\section{Literature Cited}

Allendorf, F. W., and S. R. Phelps. 1981. Use of allelic frequencies to describe population structure. Can. J. Fish. Aquat. Sci. 38: $1507-1514$.

Avise, J. C., J. Arnold, R. M. Ball Jr., E. Bermingham, T. Lamb, J. E. Neigel, C. A. Reeb, and N. C. Saunders. 1987. Intraspecific phylogeography: the mitochondrial DNA bridge between population genetics and systematics. Annu. Rev. Ecol. Syst. 18: 489-522.

Benzie, J. A. H. 1999. Major genetic differences between crownof-thorns starfish (Acanthaster planci) populations in the Indian and Pacific Oceans. Evolution 53:1782-1795.

Benzie, J. A. H., and S. T. Williams. 1995. Gene flow among giant 
clam (Tridacna gigas) populations in the Pacific does not parallel ocean circulation. Mar. Biol. 123:781-787.

1997. Genetic structure of giant clam (Tridacna maxima) populations in the west Pacific is not consistent with dispersal by present-day ocean currents. Evolution 51:768-783.

Bohonak, A. J. 1999. Dispersal, gene flow, and population structure. Q. Rev. Biol. 74:21-45.

Bonhomme, F., and S. Planes. 2000. Some evolutionary arguments about what maintains the pelagic interval in reef fishes. Environ. Biol. Fishes 59:365-383.

Bonhomme, F., K. Belkhir, P. Borsa, E. Mathieu, and M. Roux. 1993. Genetix: Logiciel d'analyse des données du groupe de génétique des populations de Montpellier. Ver. 0.1, Université Montpellier II, France.

Bossart, K., and D. R. Prowell. 1998. Genetic estimates of population structure and gene flow: limitations, lessons and new directions. Trends Ecol. Evol. 13:202-206.

Bowen, B. W., A. M. Clark, F. A. Abreu-Grobois, A. Chaves, H. A. Reichart, and R. J. Ferl. 1998. Global phylogeography of the Ridley sea turtles (Lepidochelys spp.) as inferred from mitochondrial DNA sequences. Genetica 101:179-189.

Bowen, B. W., A. M. Bass, L. A. Rocha, W. S. Grant, and D. R. Robertson. 2001. Phylogeography of the trumpetfishes (Aulostomus): ring species complex on a global scale. Evolution 55: 1029-1039.

Briggs, J. C. 1999. Coincident biogeographic patterns: Indo-west Pacific Ocean. Evolution 53:326-335.

Excoffier, L., P. Smouse, and J. Quattro. 1992. Analysis of molecular variance inferred from metric distances among DNA haplotypes: application to human mitochondrial DNA restriction data. Genetics 131:479-491.

Felsenstein, J. 1985. PHYLIP. Ver. 3.4. University Herbarium, University of California, Berkeley, CA.

Franceschinelli, S. E., and R. Kesseli. 1999. Population structure and gene flow of the Brazilian shrub Heliteres brevispira. Heredity $82: 355-363$.

Galzin, R. 1987. Structure of fish communities of French Polynesia coral reefs. 1. Spatial scales. Mar. Ecol. Prog. Ser. 41:129-136.

Gopurenko, D., J. M. Hughes, and C. P. Keenan. 1999. Mitochondrial DNA evidence for rapid colonisation of the Indo-West Pacific by the mudcrab Scylla serrata. Mar. Biol. 134:227-233.

Hellberg, M. E. 1994. Relationship between inferred levels of gene flow and geographic distance in a philopatric coral, Balanophyllia elegans. Evolution 48:1829-1854.

Hutchison, D. W., and A. R. Templeton. 1999. Correlation of pairwise genetic and geographic distance measures: inferring the relative influences of gene flow and drift on the distribution of genetic variability. Evolution 53:1898-1914.

Johnson, M. S., and R. Black. 1998. Effect of isolation by distance and geographical discontinuity on genetic subdivision of Littoratia cingulata. Mar. Biol. 132:295-303.

Jokiel, P., and F. J. Martinelli. 1992. The vortex model of coral reef biogeography. J. Biogeogr. 19:449-458.

Jones, G. P., M. J. Milicich, and C. Lunow. 1999. Self-recruitment in a coral reef fish population. Nature 402:802-804.

Kay, E. A. 1990. Cypraeidae of the Indo-Pacific: Cenozoic fossil history and biogeography. Bull. Mar. Sci. 47:23-43.

Kim, I., C. J. Philips, J. A. Monjeau, E. C. Birney, K. Noack, D. E. Pumo, R. S. Sikes, and J. A. Dole. 1998. Habitat islands, genetic diversity and gene flow in a Patagonian rodent. Mol. Ecol. 7:667-678.

Kimura, M. 1953. "Stepping stone" model of population. Annu. Rep. Nat. Inst. Genet. Jpn. 3:62-63.

Kimura, M., and G. H. Weiss. 1964. The stepping stone model of population structure and the decrease of genetic correlation with distance. Genetics 49:561-571.

Knowlton, N. 1993. Sibling species in the sea. Annu. Rev. Ecol. Syst. 24:189-216.

Lavery, S. C., D. C. Moritz, and D. R. Fielder. 1996. Indo-Pacific population structure and evolutionary history of the coconut crab Birgus latro. Mol. Ecol. 5:557-570.

Leis, J. M. 1991. The pelagic stage of reef fishes: the larval biology of coral reef fishes. Pp. 183-227 in P. F. Sale, ed. The ecology of fishes on coral reefs. Academic Press, San Diego, CA.

Lessios, H. A., B. D. Kessing, and J. S. Pearse. 2001. Population structure and speciation in tropical seas: global phylogeography of the sea urchin Diadema. Evolution 55:955-979.

Lewontin, R. C. 1985. Population genetics. Pp. 3-18 in P. J. Greenwood, P. H. Harvaey, and M. Slatkin, eds. Evolution: essays in honour of John Maynard Smith. Cambridge Univ. Press, Cambridge, U.K.

Malécot, G. 1955. The decrease of relationship with distance. Cold Springs Harbor Symp. Quant. Biol. 20:52-53.

Mantel, N. 1967. The detection of disease clustering and generalized regression approach. Cancer Res. 27:209-220.

McCormick, M. I. 1999. Delayed metamorphosis of a tropical reef fish (Acanthurus triostegus): a field experiment. Mar. Ecol. Prog. Ser. 176:25-38.

McMillan, W. O., and S. R. Palumbi. 1995. Concordant evolutionary patterns among Indo-West Pacific butterfly fishes. Proc. R. Soc. Lond. B 260:229-236.

McMillan, W. O., L. A. Weigt, and S. R. Palumbi. 1999. Color pattern evolution, assortative mating, and genetic differentiation in brightly colored butterflyfishes (Chaetodontidae). Evolution 53:247-260.

Mukai, H. 1992. Biogeography of the tropical seagrasses in the western Pacific. Aust. J. Mar. Freshwater Res. 44:1-17.

Nei, M. 1973. Analysis of gene diversity in subdivided populations. Proc. Natl. Acad. Sci. USA 70:3321-3323.

- 1978 . Estimation of average heterozygoty and genetic distance from a small number of individuals. Genetics 89:583-590.

Newman, W. A. 1986. Origin of the Hawaiian marine fauna: dispersal and vicariance as indicated by barnacles and other organisms. Pp. 21-49 in R. H. Gore and K. L. Heck, eds. Crustacean biogeography. A.A. Balkema, Rotterdam.

Newman, W. A., and B. A. Foster. 1983. The Rapanuian fauna district (Easter and Sala y Gomez): in search of ancient archipelagos. Bull. Mar. Sci. 33:633-644.

Niegel, J. E. 1997. A comparison of alternative strategies for estimating gene flow from genetic markers. Annu. Rev. Ecol. Syst. 28:105-128.

Palumbi, S. R. 1992. Marine speciation on a small planet. Trends Ecol. Evol. 7:114-118.

1997. Molecular biogeography of the Pacific. Coral Reefs 16:547-552.

Palumbi, S. R., G. Grabowsky, T. Duda, L. Geyer, and N. Tachino. 1997. Speciation and population genetic structure in tropical Pacific sea urchins. Evolution 51:1506-1517.

Pandolfi, J. M. 1992. Successive isolation rather than evolutionary centers for the origination of the Indo-Pacific reef corals. J. Biogeogr. 19:593-609.

Pasteur, N., G. Pasteur, F. Bonhomme, J. Catalan, and J. BrittonDavidian. 1987. Manuel de génétique par électrophorèses des protéines. Collection techniques et documentation, Lavoisier, Paris.

Planes, S. 1993. Genetic differentiation in relation to restricted larval dispersal of the convict surgeonfish, Acanthurus triostegus, in French Polynesia. Mar. Ecol. Prog. Ser. 98:237-246.

. 1997. Genetic diversity and dispersal capabilities in marine fish. Evol. Biol. 30:253-298.

Planes, S., F. Bonhomme, and R. Galzin. 1996. A genetic metapopulation model for reef fishes in oceanic islands: the case of the surgeonfish, Acanthurus triostegus. J. Evol. Biol. 9:103-117.

Pogson, G. H., K. A. Mesa, and R. G. Boutilier. 1995. Genetic population structure and gene flow in the Atlantic cod Gadus morhua: a comparison of allozyme and nuclear RFLP loci. Genetics 139:375-385.

Pogson, G. H., C. T. Taggart, K. A. Mesa, and R. G. Boutilier. 2001. Isolation by distance in the Atlantic cod, Gadus morhua, at large and small geographical scales. Evolution 55:131-146.

Randall, J. E. 1961. A contribution to the biology of convict surgeonfish of the Hawaiian islands, Acanthurus triostegus sandwicensis. Pac. Sci. 15:215-272.

1995. Zoogeographic analysis of the inshore Hawaiian fish fauna. Pp. 193-203 in J. E. Maragos, M. N. A. Peterson, L. G. 
Eldredge, J. E. Bardach, and H. F. Takeuchi, eds. Marine and coastal biodiversity in the tropical island Pacific region. Vol. 1, Species systematics and information management priorities. $\mathrm{Pa}$ cific Science Association, Bishop Museum, Honolulu, HI.

Raymond, M., and F. Rousset. 1995a. An exact test for population differentiation. Evolution 49:1280-1283.

1995b. GENEPOP (version 1.2): a population genetics software for exact test and ecumenicism. J. Heredity 86:248-249.

Rice, W. R. 1989. Analyzing tables of statistical tests. Evolution 43:223-225.

Rosen, B. R. 1988. Progress, problems and patterns in the biogeography of reef corals and other tropical marine organisms. Helgol. Meeresunters. 42:269-301.

Rosen, D. E. 1978. Vicariant patterns and historical explanation in biogeography. Syst. Zool. 27:159-188.

Rosenblatt, R. H., and R. S. Waples. 1986. A genetic comparison of allopatric populations of shore fish species from the eastern and central Pacific Ocean: dispersal or vicariance? Copeia 1986: $275-284$.

Rougerie, F., and B. Wauthy. 1986. L'océan qui nous entoure. Pp. 73-88 in C. Gleizal, ed. Encyclopédie de la Polynésie. Vol. 1, Les îles océaniques. Multipress, Papeete, Polynésie française.

Salvat, B. 1971. Biogéographie malacologique de la Polynésie à la lumière des récentes recherches sur l'histoire géologique des îles hautes et des atolls de cette région. Atti. Soc. Ital. Sci. Nat. Mus. Civ. Stor. Nat. Milano 112:330-334.

Shaklee, J. B., and P. Bentzen. 1998. Genetic identification of stocks of marine fish and shellfish. Bull. Mar. Sci. 62:589-621.

Shaklee, J. B., F. W. Allendorf, D. C. Morizot, and G. S. Whitt. 1990. Gene nomenclature for protein-coding loci in fish. Trans. Am. Fish. Soc. 119:2-15.

Slatkin, M. 1987. Gene flow and geographic structure of natural populations. Science 230:787-792.

. 1993. Isolation by distance in equilibrium and non-equilibrium populations. Evolution 47:264-279.

Smith, S. V. 1978. Coral-reef area and the contribution of reefs to processes and resources of the world's ocean. Nature 273: 225-226.

Springer, V. G. 1982. Pacific plate biogeography, with special reference to shorefishes. Smithsonian Contribution to Zoology. Smithsonian Institution, Washington, D.C.

Stobutzki, I., and D. R. Bellwood. 1997. Sustained swimming abilities of the late pelagic stages of coral reef fishes. Mar. Ecol. Prog. Ser. 149:35-41.
Stoddart, D. R. 1992. Biogeography of the tropical Pacific. Pacific Sci. 46:276-293.

Strickberger, M. W. 1968. Genetics. Macmillan, New York.

Swearer, S. E., J. E. Caselle, D. W. Lea, and R. R. Warner. 1999. Larval retention and recruitment in an island population of a coral-reef fish. Nature 402:799-802.

Vermeij, G. 1987. The dispersal barrier in the tropical Pacific: implications for molluscan speciation and extinction. Evolution 41: 1046-1058.

Veron, J. E. N. 1995. Corals in space and time: the biogeography and evolution of the Scleractinia. Univ. of New South Wales Press, Sydney, Australia.

Voelker, R. A., H. E. Schaffer, and T. Mukai. 1980. Spontaneous allozyme mutations in Drosophila melanogaster: rate of occurrence and nature of the mutants. Genetics 94:961-968.

Wallace, C. C., J. M. Pandolfi, R. Ross, and T. M. Cronin. 1989. Indo-Pacific coral biogeography: a case study from the Acropora selago group. Austr. Syst. Bot. - Austr. Biogeogr. 4:199-210.

Ward, R. D., M. Woodwark, and D. O. F. Skibinski. 1994. A comparison of genetic diversity levels in marine, freshwater and anadromous fishes. J. Fish Biol. 44:213-232.

Weir, B. S., and C. C. Cockerham. 1984. Estimating $F$-statistics for the analysis of population structure. Evolution 38:822-831.

Whitlock, M. C., and D. E. McCauley. 1998. Indirect measure of gene flow and migration: $F_{\mathrm{ST}} \neq(1 /(4 \mathrm{Nm}+1))$. Heredity 82 : $117-125$.

Williams, S. T., and J. A. H. Benzie. 1997. Indo-West Pacific patterns of genetic differentiation in the high dispersal starfish Linckia laevigata. Mol. Ecol. 6:559-573.

. 1998. Evidence of a biogeographic break between populations of a dispersal starfish: congruent regions within the IndoWest Pacific defined by color morphs, mtDNA, and allozymes data. Evolution 52:87-99.

Winans, G. A. 1980. Geographic variation in the milkfish Chanos chanos. I. Biochemical evidence. Evolution 34:558-574.

Wirth, T., and L. Bernatchez. 2001. Genetic evidence against panmixia in the European eel. Nature 409:1037-1040.

Wright, S. 1931. Evolution in Mendelian populations. Genetics 16: 97-159.

1943. Isolation by distance. Genetics 28:114-138.

1951. The genetical structure of populations. Ann. Eugenetics 15:322-354.

Corresponding Editor: L. Bernatchez 
APPENDIX 1.

Summary of the electrophoretic results for each Acanthurus triostegus population, each locus, overall loci and overall populations. $N$, number of fish sampled; $H$, observed heterozygosity; dash, no calculation made because the locus is monomorphic within the population considered; $P_{0.95}$ and $P_{0.99}$, percent of polymorphic loci within each population and for all populations. Significant divergences from Hardy-Weinberg equilibrium are denoted as $* P<0.05$ and $* * P<0.01$ following the $F_{\text {IS }}$-values (such an estimate does not test the $F_{\text {Is }}$-value but the HardyWeinberg equilibrium according to the GENEPOP 2.0 algorithm). Overall values consider all locations from the Pacific and Indian Oceans within a single population of 727 individuals.

\begin{tabular}{|c|c|c|c|c|c|c|c|c|}
\hline \multirow[b]{2}{*}{$\begin{array}{c}\text { Locus/ } \\
\text { population }\end{array}$} & \multirow{2}{*}{$\begin{array}{c}\begin{array}{c}\text { Indian } \\
\text { Ocean }\end{array} \\
\text { Mozambique }\end{array}$} & \multicolumn{7}{|c|}{ Pacific Ocean } \\
\hline & & Philippines & Palau & Guam & $\begin{array}{c}\text { Great Barrier } \\
\text { Reef }\end{array}$ & Solomons & $\begin{array}{c}\text { New } \\
\text { Caledonia }\end{array}$ & Fiji \\
\hline $\bar{N}$ & 40 & 38 & 41 & 40 & 40 & 39 & 123 & 39 \\
\hline \multicolumn{9}{|l|}{ Aat $-1 *$} \\
\hline$H$ & 0.100 & 0.079 & - & 0.025 & 0.025 & - & - & - \\
\hline$F_{\text {IS }}$ & -0.026 & -0.018 & - & 0.000 & 0.000 & - & - & - \\
\hline \multicolumn{9}{|l|}{ Aat-2* } \\
\hline$H$ & - & - & 0.024 & 0.175 & 0.025 & 0.154 & 0.057 & - \\
\hline$F_{\text {IS }}$ & - & - & 0.661 & 0.136 & 0.000 & -0.07 & -0.022 & - \\
\hline \multicolumn{9}{|l|}{ Aat $-3 *$} \\
\hline$H$ & 0.050 & 0.368 & 0.390 & 0.325 & 0.400 & 0.359 & 0.309 & 0.359 \\
\hline$F_{\text {IS }}$ & -0.006 & 0.267 & 0.220 & 0.115 & 0.101 & 0.270 & 0.166 & 0.247 \\
\hline \multicolumn{9}{|l|}{$A d a^{*}$} \\
\hline$H$ & 0.0250 & - & 0.073 & 0.200 & 0.025 & 0.051 & 0.033 & 0.051 \\
\hline$F_{\text {IS }}$ & 0 & - & -0.017 & 0.110 & 0.000 & -0.013 & -0.009 & -0.007 \\
\hline \multicolumn{9}{|l|}{$A d h^{*}$} \\
\hline$H$ & - & 0.079 & 0.073 & 0.150 & 0.125 & 0.128 & 0.114 & 0.026 \\
\hline$F_{\text {IS }}$ & - & $0.807 * *$ & -0.026 & -0.068 & 0.229 & $0.769 * *$ & -0.052 & $0.931 * *$ \\
\hline \multicolumn{9}{|l|}{$G d a^{*}$} \\
\hline$H$ & 0.4500 & 0.105 & 0.317 & 0.125 & 0.225 & 0.436 & 0.447 & 0.256 \\
\hline$F_{\text {IS }}$ & 0.314 & 0.297 & 0.061 & -0.054 & -0.100 & 0.132 & 0.053 & 0.434 \\
\hline \multicolumn{9}{|l|}{$G 3 p d h^{*}$} \\
\hline$H$ & 0.0500 & - & - & - & - & 0.026 & - & 0.077 \\
\hline$F_{\text {IS }}$ & -0.013 & - & - & - & - & 0.000 & - & -0.027 \\
\hline \multicolumn{9}{|l|}{ Gpi-1* } \\
\hline$H$ & 0.0250 & 0.237 & 0.342 & 0.250 & 0.225 & 0.231 & 0.285 & 0.231 \\
\hline$F_{\text {IS }}$ & 0 & 0.178 & 0.086 & 0.045 & -0.114 & 0.182 & 0.100 & 0.269 \\
\hline \multicolumn{9}{|l|}{$G p i-2 *$} \\
\hline$H$ & 0.5750 & - & - & - & 0.025 & 0.128 & 0.057 & 0.077 \\
\hline$F_{\text {IS }}$ & -0.138 & - & - & - & 0 & -0.056 & -0.025 & -0.018 \\
\hline \multicolumn{9}{|l|}{ Idhp-1* } \\
\hline$H$ & 0.025 & - & 0.024 & - & - & - & - & - \\
\hline$F_{\text {IS }}$ & 0 & - & 0.000 & - & - & - & - & - \\
\hline \multicolumn{9}{|l|}{$\operatorname{Idhp}-2 *$} \\
\hline$H$ & 0025 & 0.026 & 0.049 & 0.025 & 0.025 & 0.051 & 0.041 & 0.026 \\
\hline$F_{\text {IS }}$ & 0.000 & 0.000 & -0.013 & 0.000 & 0.000 & -0.013 & -0.012 & 0.000 \\
\hline \multicolumn{9}{|l|}{$L d h-1 *$} \\
\hline$H$ & - & 0.026 & - & - & - & - & - & - \\
\hline$F_{\text {IS }}$ & - & 0.000 & - & - & - & - & - & - \\
\hline \multicolumn{9}{|l|}{$L d h-2 *$} \\
\hline$H$ & - & - & - & 0.025 & - & - & - & - \\
\hline$F_{\text {IS }}$ & - & - & - & 0.000 & - & - & - & - \\
\hline \multicolumn{9}{|l|}{$L d h-3^{*}$} \\
\hline$H$ & - & - & - & - & - & - & - & - \\
\hline$F_{\text {IS }}$ & - & - & - & - & - & - & - & - \\
\hline \multicolumn{9}{|l|}{$M d h^{*}$} \\
\hline$H$ & 0.325 & 0.263 & 0.293 & 0.225 & 0.175 & 0.231 & 0.317 & 0.282 \\
\hline$F_{\text {IS }}$ & -0.129 & 0.138 & -0.021 & 0.186 & 0.147 & 0.182 & 0.111 & -0.002 \\
\hline \multicolumn{9}{|l|}{ Мep -1 * } \\
\hline$H$ & 0.025 & 0.316 & 0.073 & 0.075 & 0.050 & 0.128 & 0.049 & 0.077 \\
\hline$F_{\text {IS }}$ & 0.000 & 0.009 & -0.017 & -0.017 & -0.006 & -0.038 & -0.017 & -0.027 \\
\hline
\end{tabular}


APPENDIX 1. Extended.

\begin{tabular}{|c|c|c|c|c|c|c|c|c|}
\hline \multicolumn{8}{|c|}{ Pacific Ocean } & \multirow[b]{2}{*}{ Overall } \\
\hline Bora-Bora & Moorea & Fangataufa & Rangiroa & Marquesas & Oahu & Hawaii & Clipperton & \\
\hline 49 & 40 & 41 & 42 & 40 & 40 & 40 & 35 & 727 \\
\hline - & - & - & $\begin{array}{r}0.048 \\
-0.006\end{array}$ & $\begin{array}{r}0.050 \\
-0.013\end{array}$ & $\begin{array}{l}0.050 \\
0.489\end{array}$ & $\begin{array}{r}0.075 \\
-0.017\end{array}$ & $\begin{array}{r}0.086 \\
-0.030\end{array}$ & $\begin{array}{l}0.029 \\
0.078\end{array}$ \\
\hline $\begin{array}{r}0.082 \\
-0.032\end{array}$ & $\begin{array}{r}0.350 \\
-0.200\end{array}$ & $\begin{array}{r}0.146 \\
-0.067\end{array}$ & $\begin{array}{l}0.262 \\
0.011\end{array}$ & - & $\begin{array}{l}0.175 \\
0.136\end{array}$ & - & $\begin{array}{r}0.200 \\
-0.097\end{array}$ & $\begin{array}{l}0.242 \\
0.244\end{array}$ \\
\hline $\begin{array}{l}0.347 \\
0.177\end{array}$ & $\begin{array}{r}0.150 \\
-0.068\end{array}$ & $\begin{array}{l}0.293 \\
0.360\end{array}$ & $\begin{array}{l}0.191 \\
0.234\end{array}$ & $\begin{array}{l}0.250 \\
0.355^{*}\end{array}$ & $\begin{array}{l}0.475 \\
0.084\end{array}$ & $\begin{array}{l}0.475 \\
0.106\end{array}$ & $\begin{array}{l}0.229 \\
0.452\end{array}$ & $\begin{array}{l}0.316 \\
0.251\end{array}$ \\
\hline $\begin{array}{r}0.061 \\
-0.021\end{array}$ & - & - & - & - & - & $\begin{array}{r}0.050 \\
-0.013\end{array}$ & - & $\begin{array}{r}0.015 \\
-0.006\end{array}$ \\
\hline $\begin{array}{l}0.306 \\
0.101\end{array}$ & $\begin{array}{r}0.400 \\
-0.117\end{array}$ & $\begin{array}{l}0.366 \\
0.052\end{array}$ & $\begin{array}{l}0.214 \\
0.281\end{array}$ & $\begin{array}{l}0.025 \\
0.000\end{array}$ & $\begin{array}{l}0.025 \\
0.000\end{array}$ & $\begin{array}{r}0.100 \\
-0.040\end{array}$ & $\begin{array}{r}0.143 \\
-0.062\end{array}$ & $\begin{array}{l}0.223 \\
0.124\end{array}$ \\
\hline - & - & - & - & - & - & - & - & $\begin{array}{l}0.001 \\
0.000\end{array}$ \\
\hline - & - & - & - & - & - & - & - & $\begin{array}{l}0.001 \\
0.000\end{array}$ \\
\hline- & - & - & - & - & - & - & - & - \\
\hline $\begin{array}{r}0.490 \\
-0.071\end{array}$ & $\begin{array}{l}0.475 \\
0.033\end{array}$ & $\begin{array}{r}0.634 \\
-0.276\end{array}$ & $\begin{array}{r}0.619 \\
-0.302\end{array}$ & - & $\begin{array}{r}0.100 \\
-0.040\end{array}$ & $\begin{array}{r}0.150 \\
-0.068\end{array}$ & $\begin{array}{r}0.429 \\
-0.069\end{array}$ & $\begin{array}{l}0.316 \\
0.329\end{array}$ \\
\hline $\begin{array}{r}0.122 \\
-0.038\end{array}$ & $\begin{array}{r}0.075 \\
-0.017\end{array}$ & $\begin{array}{r}0.122 \\
-0.042\end{array}$ & $\begin{array}{r}0.143 \\
-0.047\end{array}$ & - & $\begin{array}{l}0.025 \\
0.000\end{array}$ & - & $\begin{array}{r}0.171 \\
-0.049\end{array}$ & $\begin{array}{r}0.085 \\
-0.001\end{array}$ \\
\hline
\end{tabular}


ApPEndix 1.

Continued.

\begin{tabular}{|c|c|c|c|c|c|c|c|c|}
\hline \multirow[b]{2}{*}{$\begin{array}{l}\text { Locus/ } \\
\text { population }\end{array}$} & \multirow{2}{*}{$\begin{array}{c}\begin{array}{c}\text { Indian } \\
\text { Ocean }\end{array} \\
\text { Mozambique }\end{array}$} & \multicolumn{7}{|c|}{ Pacific Ocean } \\
\hline & & Philippines & Palau & Guam & $\begin{array}{c}\text { Great Barrier } \\
\text { Reef }\end{array}$ & Solomons & $\begin{array}{c}\text { New } \\
\text { Caledonia }\end{array}$ & Fiji \\
\hline $\begin{array}{l} \\
\text { Mep-2* }\end{array}$ & 40 & 38 & 41 & 40 & 40 & 39 & 123 & 39 \\
\hline $\begin{array}{l}H \\
F_{\text {IS }}\end{array}$ & - & - & $\begin{array}{l}0.024 \\
0.000\end{array}$ & $\begin{array}{l}0.025 \\
0.000\end{array}$ & - & $\begin{array}{l}0.026 \\
0.000\end{array}$ & - & - \\
\hline \multicolumn{9}{|l|}{$P e p b^{*}$} \\
\hline $\begin{array}{l}H \\
F_{\text {IS }}\end{array}$ & $\begin{array}{l}0.025 \\
0.000\end{array}$ & $\begin{array}{r}0.053 \\
-0.014\end{array}$ & $\begin{array}{l}0.024 \\
0.000\end{array}$ & $\begin{array}{l}0.100 \\
-0.04\end{array}$ & $\begin{array}{l}0.025 \\
0.000\end{array}$ & $\begin{array}{r}0.051 \\
-0.007\end{array}$ & $\begin{array}{r}0.016 \\
-0.004\end{array}$ & $\begin{array}{l}0.026 \\
0.000\end{array}$ \\
\hline \multicolumn{9}{|l|}{$P g d h^{*}$} \\
\hline $\begin{array}{l}H \\
F_{\text {IS }}\end{array}$ & $\begin{array}{r}0.550 \\
-0.161\end{array}$ & $\begin{array}{l}0.211 \\
0.092\end{array}$ & $\begin{array}{r}0.317 \\
-0.048\end{array}$ & $\begin{array}{r}0.275 \\
-0.132\end{array}$ & $\begin{array}{l}0.350 \\
0.009\end{array}$ & $\begin{array}{l}0.282 \\
0.069\end{array}$ & $\begin{array}{r}0.220 \\
-0.110\end{array}$ & $\begin{array}{r}0.282 \\
-0.152\end{array}$ \\
\hline \multicolumn{9}{|l|}{$P g m *$} \\
\hline $\begin{array}{l}H \\
F_{\text {IS }}\end{array}$ & $\begin{array}{r}0.150 \\
-0.056\end{array}$ & $\begin{array}{r}0.132 \\
-0.057\end{array}$ & $\begin{array}{r}0.171 \\
-0.081\end{array}$ & $\begin{array}{r}0.100 \\
-0.026\end{array}$ & $\begin{array}{l}0.150 \\
0.179\end{array}$ & $\begin{array}{r}0.128 \\
-0.035\end{array}$ & $\begin{array}{l}0.122 \\
0.071\end{array}$ & $\begin{array}{l}0.154 \\
0.187\end{array}$ \\
\hline \multicolumn{9}{|l|}{ Overall } \\
\hline $\begin{array}{l}P_{0.95} \\
P_{0.99} \\
H \\
F_{\text {IS }}\end{array}$ & $\begin{array}{c}0.30 \\
0.70 \\
0.120 \\
-0.055\end{array}$ & $\begin{array}{l}0.40 \\
0.60 \\
0.095 \\
0.246 * *\end{array}$ & $\begin{array}{l}0.30 \\
0.70 \\
0.110 \\
0.073\end{array}$ & $\begin{array}{l}0.50 \\
0.75 \\
0.105 \\
0.046\end{array}$ & $\begin{array}{l}0.35 \\
0.70 \\
0.093 \\
0.053\end{array}$ & $\begin{array}{l}0.50 \\
0.75 \\
0.121 \\
0.230 * *\end{array}$ & $\begin{array}{l}0.35 \\
0.60 \\
0.103 \\
0.062\end{array}$ & $\begin{array}{l}0.35 \\
0.65 \\
0.096 \\
0.277 * *\end{array}$ \\
\hline \multicolumn{9}{|c|}{ Overall (without $A d h *$ ) } \\
\hline $\begin{array}{l}P_{0.95} \\
P_{0.99} \\
H \\
F_{\text {IS }}\end{array}$ & $\begin{array}{c}0.32 \\
0.74 \\
0.126 \\
-0.055\end{array}$ & $\begin{array}{l}0.37 \\
0.58 \\
0.096 \\
0.136\end{array}$ & $\begin{array}{l}0.32 \\
0.68 \\
0.112 \\
0.076\end{array}$ & $\begin{array}{l}0.47 \\
0.74 \\
0.103 \\
0.054\end{array}$ & $\begin{array}{l}0.32 \\
0.68 \\
0.091 \\
0.037\end{array}$ & $\begin{array}{l}0.47 \\
0.74 \\
0.121 \\
0.114\end{array}$ & $\begin{array}{l}0.32 \\
0.58 \\
0.103 \\
0.068\end{array}$ & $\begin{array}{l}0.32 \\
0.63 \\
0.100 \\
0.171\end{array}$ \\
\hline
\end{tabular}


APPENDIX 1.

Continued Extended.

\begin{tabular}{|c|c|c|c|c|c|c|c|c|}
\hline \multicolumn{8}{|c|}{ Pacific Ocean } & \multirow[b]{2}{*}{ Overall } \\
\hline Bora-Bora & Moorea & Fangataufa & Rangiroa & Marquesas & Oahu & Hawaii & Clipperton & \\
\hline 49 & 40 & 41 & 42 & 40 & 40 & 40 & 35 & 727 \\
\hline $\begin{array}{l}0.020 \\
0.000\end{array}$ & $\begin{array}{l}0.025 \\
0.000\end{array}$ & - & - & - & - & - & $\begin{array}{l}0.314 \\
0.081\end{array}$ & $\begin{array}{l}0.022 \\
0.191\end{array}$ \\
\hline $\begin{array}{l}0.020 \\
0.000\end{array}$ & - & - & $\begin{array}{l}0.024 \\
0.000\end{array}$ & $\begin{array}{l}0.025 \\
0.000\end{array}$ & $\begin{array}{l}0.275 \\
0.123\end{array}$ & $\begin{array}{r}0.325 \\
-0.014\end{array}$ & - & $\begin{array}{l}0.056 \\
0.103\end{array}$ \\
\hline $\begin{array}{r}0.225 \\
-0.084\end{array}$ & $\begin{array}{r}0.200 \\
-0.099\end{array}$ & $\begin{array}{r}0.293 \\
-0.144\end{array}$ & $\begin{array}{r}0.167 \\
-0.079\end{array}$ & - & $\begin{array}{r}0.550 \\
-0.242\end{array}$ & $\begin{array}{l}0.325 \\
0.308\end{array}$ & $\begin{array}{l}0.143 \\
0.220\end{array}$ & $\begin{array}{l}0.268 \\
0.200\end{array}$ \\
\hline $\begin{array}{r}0.184 \\
-0.072\end{array}$ & $\begin{array}{l}0.175 \\
0.136\end{array}$ & $\begin{array}{r}0.098 \\
-0.022\end{array}$ & $\begin{array}{r}0.095 \\
-0.028\end{array}$ & - & $\begin{array}{r}0.200 \\
-0.063\end{array}$ & $\begin{array}{r}0.225 \\
-0.068\end{array}$ & $\begin{array}{l}0.086 \\
0.366\end{array}$ & $\begin{array}{l}0.135 \\
0.043\end{array}$ \\
\hline $\begin{array}{l}0.40 \\
0.70 \\
0.153 \\
0.024\end{array}$ & $\begin{array}{l}0.45 \\
0.65 \\
0.143 \\
0.060\end{array}$ & $\begin{array}{l}0.45 \\
0.60 \\
0.181 \\
0.005\end{array}$ & $\begin{array}{c}0.45 \\
0.65 \\
0.161 \\
-0.002\end{array}$ & $\begin{array}{l}0.20 \\
0.40 \\
0.045 \\
0.198\end{array}$ & $\begin{array}{l}0.45 \\
0.65 \\
0.108 \\
0.194 \text { ** }\end{array}$ & $\begin{array}{l}0.35 \\
0.55 \\
0.104 \\
0.059\end{array}$ & $\begin{array}{l}0.55 \\
0.65 \\
0.161 \\
0.053\end{array}$ & $\begin{array}{l}0.50 \\
0.75 \\
0.117 \\
0.276 \text { ** }\end{array}$ \\
\hline $\begin{array}{l}0.37 \\
0.68 \\
0.127 \\
0.034\end{array}$ & $\begin{array}{l}0.42 \\
0.63 \\
0.134 \\
0.100\end{array}$ & $\begin{array}{l}0.42 \\
0.58 \\
0.162 \\
0.018\end{array}$ & $\begin{array}{c}0.42 \\
0.63 \\
0.148 \\
-0.040\end{array}$ & $\begin{array}{l}0.16 \\
0.37 \\
0.040 \\
0.202\end{array}$ & $\begin{array}{l}0.42 \\
0.63 \\
0.103 \\
0.215 \text { ** }\end{array}$ & $\begin{array}{l}0.32 \\
0.53 \\
0.095 \\
0.085\end{array}$ & $\begin{array}{l}0.53 \\
0.63 \\
0.143 \\
0.095\end{array}$ & $\begin{array}{l}0.47 \\
0.74 \\
0.112 \\
0.241 \text { ** }\end{array}$ \\
\hline
\end{tabular}




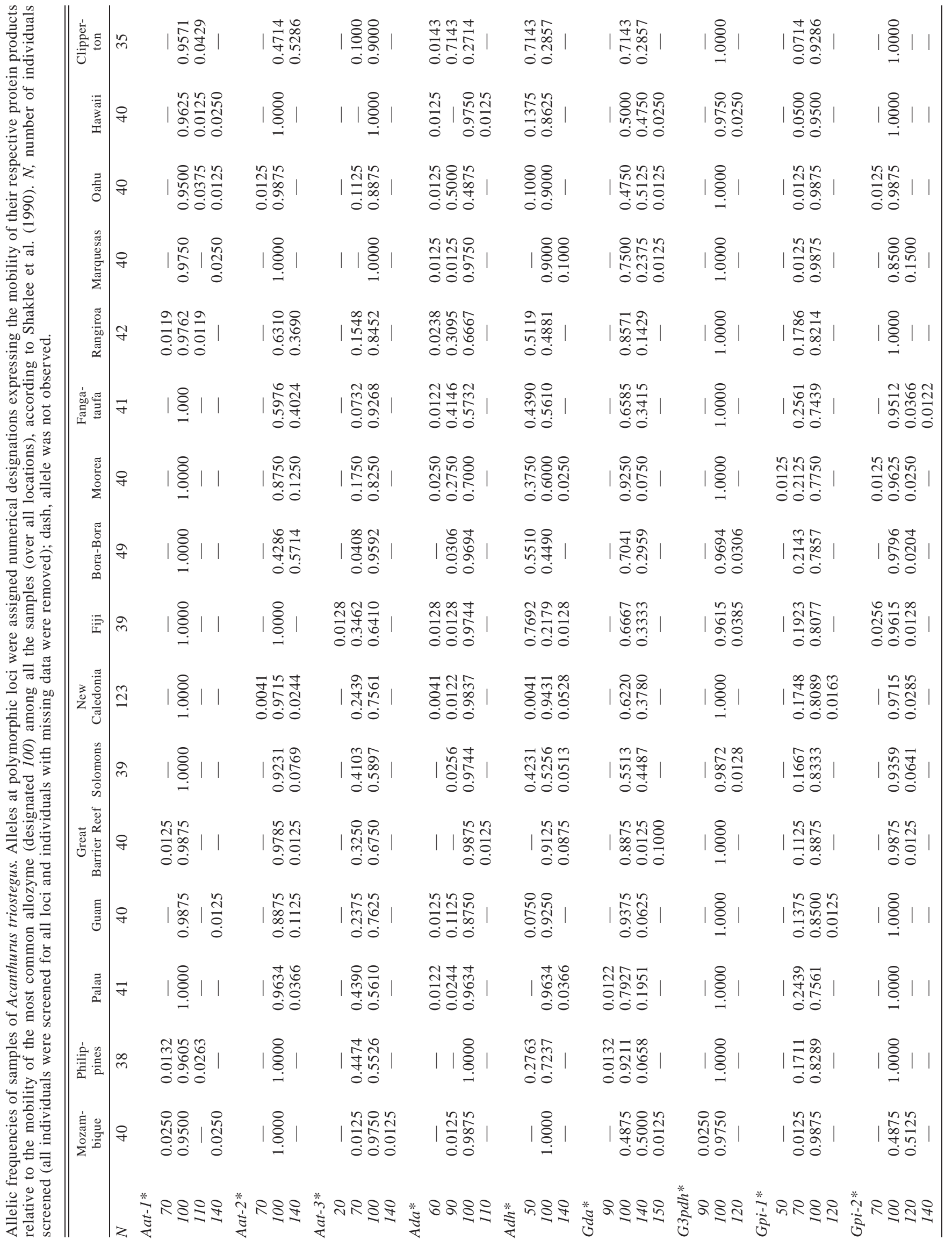




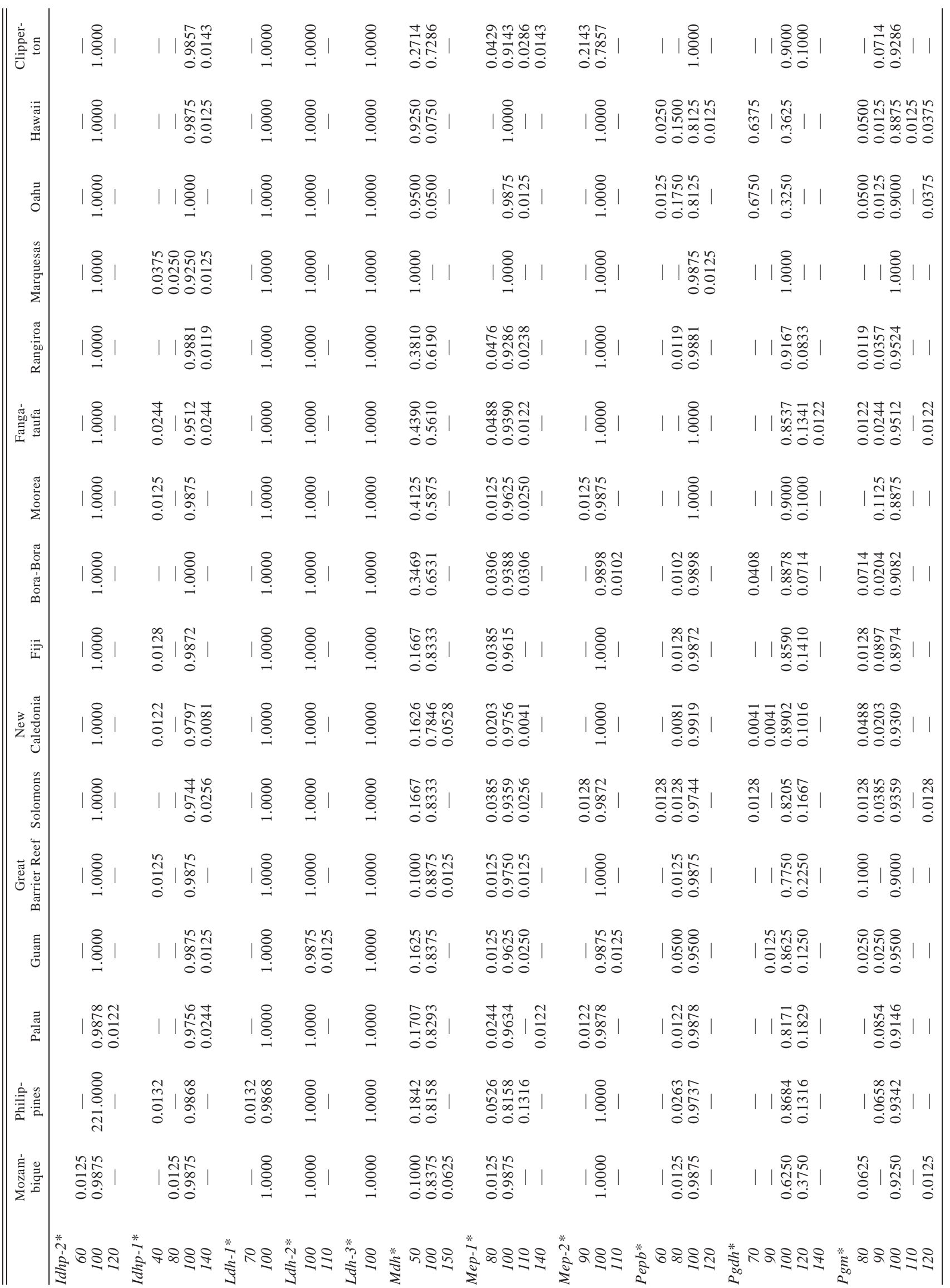

